\title{
A Muscle Acetylcholine Receptor Is Expressed in the Human Cerebellar Medulloblastoma Cell Line TE671
}

\author{
Michael A. Luther, ${ }^{1}$ Ralf Schoepfer, ${ }^{1}$ Paul Whiting, ${ }^{1}$ Brett Casey, ${ }^{1}$ Yoav Blatt, ${ }^{2, a}$ Myrta S. Montal, ${ }^{2}$ Mauricio \\ Montal, ${ }^{2}$ and Jon Lindstrom' \\ 1The Salk Institute for Biological Studies, San Diego, California 92138, and 2University of California, San Diego, La Jolla, \\ California 92093-0319
}

The human neuromedulloblastoma cell line TE671 is shown by single-channel recordings to express nicotinic acetylcholine receptors (AChRs) that are blocked by $\alpha$-bungarotoxin $(\alpha B g t)$. These AChRs do not react with antisera to the $\alpha$ Bgt-binding protein of brain or with monoclonal antibodies (mAbs) to brain nicotinic AChRs that do not bind $\alpha$ Bgt. TE671 AChRs do react with autoantibodies to muscle AChRs from myasthenia gravis patients and with mAbs to muscle AChRs, including mAbs specific for extrajunctional AChRs. AChRs purified from TE671 cells are composed of 4 kinds of subunits corresponding to those of muscle AChR. Sequences of cDNAs for the ACh-binding $\alpha$ subunit and the $\delta$ subunit of this AChR further identify it as muscle AChR. Expression of TE671 AChR can be up-regulated by nicotine and dexamethasone, and down-regulated by forskolin.

The nicotinic acetylcholine receptor $(\mathrm{AChR})$ family includes muscle-type AChRs, neuronal AChRs, and neuronal $\alpha$-bungarotoxin ( $\alpha \mathrm{Bgt})$-binding proteins, all of which exhibit related but distinct biochemical properties (reviewed by Lindstrom et al., 1987b). AChRs from muscle and fish electric organs are composed of 4 kinds of homologous subunits, which form an AChregulated cation channel that can be competitively inhibited by $\alpha$ Bgt. AChRs from neurons also contain an ACh-regulated cation channel but, in contrast, do not bind $\alpha \mathrm{Bgt}$ and are composed of only 2 kinds of homologous subunits. Neuronal $\alpha$ Bgt-binding proteins do not have an $\mathrm{ACh}$-regulated cation channel and may have 4 kinds of subunits. Despite little immunological crossreaction between these proteins, the subunits have substantial sequence identity, suggesting a common ancestral origin.

Myasthenia gravis (MG) is an autoimmune disease mediated by antibodies to muscle AChRs (reviewed by Lindstrom et al., 1988). Research into the mechanisms responsible for this disease has been somewhat hindered by the lack of human muscle

Received May 26, 1988; revised July 18, 1988; accepted July 22, 1988.

We thank Drs. Jim Boulter and Steve Heinemann for providing cDNA probes for $\alpha, \beta, \gamma$, and $\delta$ subunits of $\mathrm{AChR}$ from the mouse $\mathrm{BC} 3 \mathrm{H} 1$ cell line, and $\mathrm{Dr}$. Mark McNamee for ${ }^{3} \mathrm{H}-\mathrm{MBTA}$. This work was supported by research grants from the NIH (NS1 1323), the U.S. Army (DAMD17-86-C-6148), the Muscular Dystrophy Association, the Alexander Onassis Public Benefit Foundation, The Council for Tobacco Research-U.S.A., and the Los Angeles and California Chapters of the Myasthenia Gravis Foundation. M.L. is an MDA Postdoctoral Fellow. R.S. was supported by a Deutsche Forschungsgemeinschaft Fellowship.

Correspondence should be addressed to Jon Lindstrom. The Salk Institute for Biological Studies, Receptor Biology Laboratory, P.O. Box 85800, San Diego, CA 92138.

a Present address: Bio-Dar Ltd., Kiryat Weizmann, P.O. Box 2142, Rehovot 76110 , Israel.

Copyright (C) 1989 Society for Neuroscience $0270-6474 / 89 / 031082-15 \$ 02.00 / 0$ cell lines. Thus, despite the limited cross-reaction with rodent AChRs, the effects of MG patient sera antibodies are often studied on rodent muscle cell lines. Further, human muscle AChRs for diagnostic assays are usually obtained from leg amputations, a highly variable and unreliable source.

The human cell line TE671, established by McAllister et al. (1977) from an undifferentiated cerebellar tumor, expresses functional $\mathrm{AChRs}$ that bind $\alpha \mathrm{Bgt}$. These receptors were originally characterized as neuronal AChRs equivalent to the $\alpha \mathrm{Bgt}-$ binding protein in brain (Syapin et al., 1982; Lukas et al., 1986a, b; Siegel and Lukas, 1988); however, studies from this laboratory suggest that TE671 cells, in fact, express musclelike AChRs. For example, MG patient autoantibodies immunoprecipitate ${ }^{125} \mathrm{I}-\alpha$ Bgt-labeled AChRs from TE671 cells as effectively as they do ${ }^{125}$ I- $\alpha$ Bgt-labeled AChRs from human muscle (Lindstrom et al., 1987a), while these autoantibodies do not immunoprecipitate ${ }^{125} \mathrm{I}-\alpha$ Bgt-labeled proteins from human brain (Whiting et al., 1987). Furthermore, monoclonal antibodies (mAbs) specific for rat brain AChRs, which do not immunoprecipitate AChRs from TE671 cells, will bind AChRs from human brain that exhibit a high affinity for nicotine and no affinity for $\alpha \mathrm{Bgt}$ (Whiting et al., 1987; Whiting and Lindstrom, 1988). These human brain AChRs also do not bind MG patient autoantibodies. Finally, a cloned cDNA for the ACh-binding $\alpha$ subunit of TE671 AChR (Schoepfer et al., 1988) has the identical sequence predicted from a genomic clone for the $\alpha$ subunits of human muscle AChRs (Noda et al., 1983a).

Here we report a multidisciplinary characterization of the TE671 AChR, establishing in detail that it is a muscle-type nicotinic AChR: (1) electrophysiological studies suggesting that AChRs from TE671 resemble those from muscle at the singlechannel level; (2) immunological studies indicating that AChRs from TE671 resemble extrajunctional AChRs from muscle but not AChRs from brain; (3) biochemical studies demonstrating that AChRs purified from TE671 cells are composed of 4 kinds of subunits similar to those of muscle AChRs; (4) molecular genetic studies showing that the $\delta$ subunits of AChR from TE671 cells have the amino acid sequence expected of $\delta$ subunits from muscle AChRs; and (5) cell biology studies revealing that AChR expression is up-regulated by nicotine, human calcitonin generelated peptide (hCGRP), or dexamethasone, and reduced by forskolin, which also inhibits cell division and promotes the development of extensive neuronlike processes.

Our identification of a human cell line that expresses a functional skeletal musclelike AChR should be beneficial for studies on the structure and function of human muscle AChRs at the protein, mRNA, and DNA levels, and also for studying the various mechanisms of regulation of AChR expression in this 
cell line. Further, it should also prove useful for studies of MG, both as a consistent and unlimited source of antigen for biochemical studies and for studying the effects of autoantibodies on AChR function and turnover.

\section{Materials and Methods}

TE6 71 cells. Cultures were grown at $37^{\circ} \mathrm{C}$ in $90 \%$ air $/ 10 \% \mathrm{CO}_{2}$ in Iscove's modified Dulbecco's medium from Irvine Laboratories supplemented with either $10 \%$ fetal bovine serum or $5 \%$ bovine calf serum. For electrophysiological studies, $10^{4}$ cells were plated per well in a 24 well plate on 12 -mm-diameter glass coverslips in medium with $10 \%$ serum. One day later, serum was reduced to $0.01 \%$, and $2 \mathrm{mM} \mathrm{L-glu-}$ tamine, $10 \mu \mathrm{g} / \mathrm{ml}$ insulin, and transferrin were added. Electrophysiological studies were done in $115 \mathrm{~mm} \mathrm{NaCl}, 5 \mathrm{~mm} \mathrm{CsCl}, 1 \mathrm{~mm} \mathrm{MgCl}_{2}$, $25 \mathrm{~mm}$ glucose, $25 \mathrm{~mm}$ HEPES, pH 7.4, $10 \mathrm{~mm}$ TEA, and $0.1 \mathrm{~mm}$ anthracene-9-carboxylic acid.

Fluorescent labeling. Cells on coverslips were incubated with $10^{-7} \mathbf{M}$ $\mathrm{mAb}$ for $30 \mathrm{~min}$, rinsed with $0.15 \mathrm{M} \mathrm{NaCl}, 15 \mathrm{~mm} \mathrm{Na}$ phosphate, $\mathrm{pH}$ 7.4 , incubated with rabbit anti-rat $\operatorname{IgG}(85 \mu \mathrm{g} / \mathrm{ml})$, rinsed, incubated with rhodamine-labeled, affinity-purified goat anti-rabbit IgG $(10 \mu \mathrm{g} /$ $\mathrm{ml}$ ), and rinsed again. A Zeiss photomicroscope equipped with Nomarski optics and a fluorescent attachment $(556 \mathrm{~nm}$ bandpass excitation filter, $590 \mathrm{~nm}$ barrier filter) was used at $63 \times$ magnification.

Electrical recordings. Single-channel current electrical recordings were performed as previously described in detail (Sakmann and Neher, 1983). Recordings were obtained in both the cell attached and the excised patch configurations. The pipettes were fabricated from Kovar glass (Corning $7052, \mathrm{ID}=1.1 \mathrm{~mm}, \mathrm{OD}=1.5 \mathrm{~mm}, 70 \mathrm{~mm}$ long) using a vertical pipette puller (David Kopf $700 \mathrm{C}$, Tujunga, CA). The pipettes were coated with Sylgard-180 (Dow Corning) within $40 \mu \mathrm{m}$ from the tip and fire-polished immediately before use under $320 \times$ magnification. The tip size was adjusted to yield 5-15 M of open pipette resistance when filled and immersed in the buffer described before. The patch pipettes contained the indicated concentration of $\mathrm{ACh}$ diluted in the same solution. The cells were observed with an inverted microscope (Nikon -Diaphot) using a $40 \times$ objective (LWD DL 40XC, Nikon) equipped with Hoffman modulation contrast optics (Modulation Optics, Greenvale, NY). The microscope was mounted on a vibration isolation table (Micro $\mathrm{g}$ Technical Mfrg. Corp., Waltham, MA).

A commercially available extracellular patch-clamp system was used (LM EPC-5, List Electronics, Darmstadt, FRG, and Medical Systems Corporation, New York). The headstage of the amplifier was mounted on a hydraulic micromanipulator (MO-103N Narishige, Japan). The signal output from the clamp was recorded on FM tape (Racal 4DS, Hythe, Southhampton, England; bandwidth DC $-5 \mathrm{kHz}$ ). All the records were filtered at $2 \mathrm{kHz}$ on an 8 -pole Bassel low-pass filter (Frequency Devices, 9028LPF, Haverhill, MA). The data were digitized at the sampling frequency of $10 \mathrm{kHz}$ in an Indec-L-11/73-70 microcomputer system (Indec, Sunnyvale CA). Conductance levels were discriminated as described previously (Labarca et al., 1984). Histograms of dwell times in the open and closed states of the AChR channel were analyzed as described in detail previously (Labarca et al., 1984, 1985; Montal et al., 1986). The results of at least 5 different experiments in each condition are presented. All experiments were done at room temperature $\left(22^{\circ} \mathrm{C}\right)$.

Preparation of solubilized TE67 1 membrane extracts. TE671 cell cultures were grown in T-flasks for $6 \mathrm{~d}$ and then expanded to 2 liter $(850$ $\mathrm{cm}^{2}$ ) roller bottles in 5\% BCS in Iscove's modified DMEM medium (Irvine Laboratories) with $2.5 \mu \mathrm{M}$ dexamethasone. Atter $10 \mathrm{~d}$ in culture the cells were harvested after aspiration of media by first rinsing with cold PBS, pH 7.5, containing $10 \mathrm{~mm}$ iodoacetamide (IAA), $10 \mathrm{~mm}$ aminobenzamidine, $1 \mathrm{~mm}$ phenylmethylsulfonylfluoride (PMSF) to remove the excess media, and second by shaking in $25 \mathrm{ml}$ per bottle of $50 \mathrm{~mm}$ Tris, $150 \mathrm{~mm} \mathrm{NaCl}, 100 \mathrm{~mm}$ KF, $5 \mathrm{~mm}$ FDTA, $5 \mathrm{~mm}$ FGTA, $5 \mathrm{~mm}$ IAA, $5 \mathrm{~mm}$ aminobenzamidine, $0.5 \mathrm{~mm}$ PMSF, bestatin $(10 \mu \mathrm{g} /$ $\mathrm{ml}$ ), Trasylol $(10 \mu \mathrm{g} / \mathrm{ml})$, soybean trypsin inhibitor $(10 \mu \mathrm{g} / \mathrm{ml}), \mathrm{pH} 7.5$ (buffer A). The bottles were then rinsed with 4 volumes of buffer $A$ to remove any remaining cells. The cells were then pelleted by centrifugation at $3000 \times g$ for $30 \mathrm{~min}$. The resulting cell pellet was resuspended in $400 \mathrm{ml}$ of buffer $\mathrm{A}$, lysed by homogenization using a Polytron for 30 $\mathrm{sec}$, and centrifuged for $30 \mathrm{~min}$ at $10,000 \times \mathrm{g}$. The membrane pellet was resuspended in $250 \mathrm{ml}$ of buffer $\mathrm{A}$, homogenized, and centrifuged as described in the previous step. The resulting pellet was then extracted for $30 \mathrm{~min}$ in 4 volumes of buffer $A$ with $1 \%$ Thesit detergent (Boeh- ringer) and $0.05 \%$ SDS, pH 7.5, centrifuged at $140,000 \times g$ for $30 \mathrm{~min}$, and the clarified supernatant was retained.

Purification of the TE671 AChR. $\alpha$ Bgt was first coupled to Sepharose CL4B at $5.0 \mathrm{mg}$ protein $/ \mathrm{ml}$ of gel by a modified procedure of Kohn and Wilchek (1982) (D. Shelton, Y. Fujii, W. Knogge, and J. Lindstrom, unpublished data). The clarified, solubilized TE671 membrane extract $(75-100 \mathrm{ml})$ from, typically, 12 roller bottles, was applied to a $20 \mathrm{ml}$ column of Sepharose CL $4 B$ to adsorb any proteins that may nonspecifically adsorb to the column. The eluate was then applied to a $1 \mathrm{ml}$ column of $\alpha$ Bgt-affinity gel, and both columns were washed with 200 $\mathrm{ml}$ of the extraction buffer. The affinity column was consecutively washed with $200 \mathrm{ml}$ of buffer $\mathrm{A}$ containing $1.0 \mathrm{M} \mathrm{NaCl}, 0.5 \%$ Thesit, $0.05 \%$ SDS, pH 7.5, followed by $150 \mathrm{ml}$ of $10 \mathrm{~mm}$ Tris, $0.1 \%$ Thesit, $1 \mathrm{~mm}$ $\mathrm{NaN}_{3}, 10 \mathrm{~mm} \mathrm{KF}, 1 \mathrm{~mm}$ IAA, $1 \mathrm{~mm}$ aminobenzamidine, $1 \mathrm{~mm}$ EDTA, and 1 mM EGTA pH 7.5 (buffer B). The affinity column was then coupled to a hydroxylapatite (HPT) column $(1 \mathrm{ml})$ and the TE671 AChR eluted onto the HPT column by recirculating through both columns for $12 \mathrm{hr}$, $10 \mathrm{ml}$ of buffer B containing $200 \mathrm{~mm}$ carbamylcholine, using a peristaltic pump. After displacement of the bound protein, the HPT column was washed with $200 \mathrm{ml}$ of buffer $B$ and then eluted with $150 \mathrm{~mm}$ sodium phosphate, $0.5 \%$ Thesit, $1 \mathrm{~mm} \mathrm{NaN}_{3}, 1 \mathrm{~mm}$ PMSF, 1 mM EDTA, $1 \mathrm{~mm}$ EGTA, 1 mM aminobenzamidine, and $1 \mathrm{~mm}$ IAA at $\mathrm{pH} 7.5$.

Affinity labeling. TE671 AChR was immobilized on $\alpha$ Bgt-Sepharose and then affinity-labeled with ${ }^{3} \mathrm{H}-\mathrm{MBTA}$ (a gift from Dr. Mark McNamee) as previously described (Whiting and Lindstrom, 1987).

Electrophoresis. Electrophoresis was conducted on acrylamide slab gels in SDS using a Laemmli discontinuous buffer system (Laemmli, 1970). Polyacrylamide gels were silver-stained for protein according to the method of Oakley et al. (1980). Polyacrylamide gels of radiolabeled protein were autoradiographed for $4-24 \mathrm{hr}$ at $-70^{\circ} \mathrm{C}$ using preflashed Kodak X-Omat-AR film and an intensifying screen. Autoradiograms were standardized by using Sigma prestained low-molecular-weight standards resolved on the same gel. Electrophoretic transfer of proteins from gels to diazophenylthioether (DPT) paper and subsequent probing with antibodies were as described previously (Gullick and Lindstrom, 1982). After being probed, bound antibodies were detected by incubation with $0.5 \mathrm{~nm}{ }^{125} \mathrm{I}$-labeled mouse anti-rat $\mathrm{IgG}\left(1-3 \times 10^{18} \mathrm{cpm} /\right.$ mol) and autoradiography.

Cloning and sequencing of TE67I AChR $\delta$ subunit cDNA. A cDNA library was preparcd as previously described (Schoepfer et al., 1988). The filters were screened under high stringency with the $\sim 450$ base pair (bp) Eco RI-Ava I fragment of cDNA clone BMD451 (a gift of Dr. Jim Boulter) coding for the $114 \mathrm{~N}$ terminal amino acids of the mouse AChR $\delta$ subunit. A single positive clone was identified. Plasmid DNA was characterized by restriction enzyme digestion, followed by agarose gel electrophoresis and Southern blot analysis. From the $\sim 3 \mathrm{~kb}$ insert, the $5^{\prime} \sim 1860$ bp Eco-Ava fragment was subcloned into a plasmid vector. Nested deletions were produced by the Exo III/Mung Bean protocol provided by Stratagene. DNA sequencing was performed using a modification of the dideoxynucleotide chain termination method of Sanger et al. (1977).

Regulation of TE671 expression. Cultured cells grown in T-flasks were harvested and $1 \times 10^{5}$ cells were plated in 6-well tissue culture dishes in Iscove's medium containing $10 \%$ FCS. After $2 \mathrm{~d}$, the media was removed and replaced with this medium containing the indicated concentrations of forskolin, nicotine, human CGRP (a gift from Dr. Jean Rivier), or dexamethasone. Forskolin and dexamethasone were dissolved in $95 \%$ ethanol, while CGRP was dissolved in PBS. Ethanol or PBS alone had no affect on cell growth or AChR expression. The cells were grown for $2 \mathrm{~d}$ and the number of $\alpha$-Bgt binding sites, AChR function, and RNA encoding the $\alpha, \beta, \gamma$, and $\delta$ subunits of the TE671 AChR were determined.

The number of $\alpha \mathrm{Bgt}$ binding sites was determined as follows. After $2 \mathrm{~d}$ the medium was removed, and the cells were washed 3 times with $2 \mathrm{ml}$ of Iscove's media. The cells were then labeled for $1 \mathrm{hr}$ with 0.5 $\mathrm{ml}$ of $20 \mathrm{nM}^{125} \mathrm{I}-\alpha \mathrm{Bgt}$ in Iscove's medium at $37^{\circ} \mathrm{C}$. Nonspecific binding was determined by performing the experiments as described, in the presence of $1 \mathrm{~mm}$ carbamylcholine. After $1 \mathrm{hr}$, the cells were again washed 3 times with $2 \mathrm{ml}$ Iscove's medium. The cells were solubilized with $1.5 \mathrm{ml}$ of $0.5 \mathrm{~N} \mathrm{NaOH}$, removed, and bound ${ }^{125}$ I- $\alpha$ Bgt determined by gamma counting.

AChR function was measured by carbamylcholine-induced influx of ${ }^{86} \mathrm{Rb}^{+}$using a modified procedure of Robinson and McGee (1985). Briefly, after $2 \mathrm{~d}$ of growth in the presence or absence of the various indicated effectors, the media was removed and the cells washed 3 times with 2.0 
$\mathrm{ml}$ Iscove's. After the third wash, the cells were incubated for $1 \mathrm{hr}$ in $0.5 \mathrm{ml}$ Iscove's to allow recovery from desensitization of AChRs by the effectors. Media was removed and the cells washed 2 times with $2.0 \mathrm{ml}$ $0.5 \mathrm{M}$ sucrose, $5 \mathrm{~mm} \mathrm{KCl}, 10 \mathrm{~mm}$ glucose, $1.8 \mathrm{mM} \mathrm{CaCl}_{2}$, and $15 \mathrm{~mm}$ HEPES, $\mathrm{pH}$ 7.4. The cells were then washed with $0.5 \mathrm{ml}$ of the same buffer with $2 \mathrm{~mm}$ ouabain for $20 \mathrm{sec}$ to inhibit $\mathrm{Na}^{+}-\mathrm{K}^{+}$ATPases. The buffer was removed and ${ }^{86} \mathrm{Rb}^{+}$uptake was initiated by exposing cells to $0.5 \mathrm{ml}$ of the ouabain buffer containing $5 \mu \mathrm{Ci} / \mathrm{ml}$ of ${ }^{86} \mathrm{Rb}^{+}$with $1 \mathrm{~mm}$ carbamylcholine. Control experiments were performed as described, in the absence of carbamylcholine. Uptake was terminated after $30 \mathrm{sec}$ by aspirating the radioactive solution and rapidly washing 3 times with 3 $\mathrm{ml}$ of $0.3 \mathrm{M} \mathrm{NaCl}, 5 \mathrm{mM} \mathrm{KCl}, 1.8 \mathrm{nM} \mathrm{CaCl}_{2}, 10 \mathrm{~mm}$ glucose, and 15 mM HEPES, $\mathrm{pH} 7.5$. The washed cells were solubilized with $1.5 \mathrm{ml} 0.5$ $\mathrm{N} \mathrm{NaOH}$ to permit ${ }^{86} \mathrm{Rb}^{+}$uptake and protein determination. Radioactivity was determined by liquid scintillation counting of the solubilized cells. Results were normalized as described for the determination of $\alpha \mathrm{Bgt}$ binding sites.

Total RNA was isolated by the guanidine thiocyanate- $\mathrm{CsCl}$ procedure of Chirgwin et al. (1979). The amount of RNA isolated was quantitated by $\mathrm{OD}_{260}$, and equal amounts of RNA from each treatment were sizefractionated by agarose gel electrophoresis containing formaldehyde. The gel was transferred to Nylon membranes and probed (Fig. 8) with cloned cDNA inserts (gifts from Dr. Jim Boulter) for the $\alpha, \beta$, and $\gamma$ subunits of mouse muscle AChR (Heinemann et al., 1986), and the $\delta$ subunit probe was derived from the cDNA clone for TE671 $\delta$. Hybridization was conducted under highly stringent conditions: $42^{\circ} \mathrm{C}, 50 \%$ formamide, $5 \times$ SSPE, final washing at $65^{\circ} \mathrm{C}, 0.3 \times$ SSPE (where $5 \times$ SSPE is $0.9 \mathrm{~m} \mathrm{NaCl}, 50 \mathrm{~mm}$ Na phosphate, pH 7.4, 5 mм EDTA). Autoradiography was performed as described above.

Poly $\mathrm{A}^{+}$RNA was prepared from total RNA by oligo-dT column chromatography. The mRNA species for $\alpha, \beta, \gamma$, and $\delta$ was identified as above using mouse muscle cDNA probes (Heinemann et al., 1986).

\section{Results and Discussion}

\section{AChRs are localized on the surface of some TE671 cells}

Fluorescent labeling indicates that AChRs are present on the surface of some cells in a serum-starved TE671 culture but not others (Fig. 1). AChRs were identified using $3 \mathrm{mAbs}$ directed at the main immunogenic region (MIR) on the extracellular surface of $\alpha$ subunits, raised against AChRs from Electrophorus (mAb 35), human muscle (mAb 203), and muscle of mice and cattle (mAb 210) (Tzartos et al., 1981, 1983, 1987). Each showed equivalent results. Under the serum starvation conditions used for electrophysiological studies, labeling of only about $60 \%$ of cells grown on coverslips is observed. From these results it is not evident whether several clonal types are present, or whether a pluripotent clonal type undergoes partial differentiation under these culture conditions.

\section{AChRs from TE671 cells are not of the neuronal type}

AChRs solubilized from TE671 cells and labeled with ${ }^{125}[-\alpha B g t$ are not immune precipitated by a 400 -fold molar excess of antiserum to the $\alpha$ Bgt-binding protein purified from chicken brain (data not shown). This high-titer antiserum precipitates 5 $\mu \mathrm{mol}$ of $\alpha \mathrm{Bgt}$ binding sites from chicken brain per liter of serum and cross-reacts $0.8 \%$ with the $\alpha$ Bgt-binding protein from human brain. The antiserum also shows no reaction on Western blots of purified TE671 AChR under conditions where antisera to AChR purified from TE671 label corresponding subunits from AChRs of TE671 and Torpedo electric organ (M. Luther and J. Lindstrom, unpublished observations). This data, along with the fact that mAbs like 35, 203, and 210, and MG patient autoantibodies bind AChR from TE671 but not $\alpha$ Bgt-binding proteins from human brain (Whiting et al., 1987), suggest that TE671 AChRs are not identical to the common $\alpha$ Bgt-binding proteins from human brain.

AChRs solubilized from TE671 cells and labeled with ${ }^{125}$ I- $\alpha$ Bgt were also not immune precipitated by a 100 -fold molar excess of mAbs 290, 293, or 299, which react with AChRs from human brain that have high affinity for nicotine but do not bind $\alpha B g t$ (Whiting et al., 1987; Whiting and Lindstrom, 1988). Thus, TE671 AChRs are also different from AChRs detected in adult human brain.

\section{Functional AChRs are detected on TE67 1 cells}

The observation of Syapin et al. (1982) that these AChRs could be blocked by $\alpha$ Bgt by measuring carbamylcholine-induced ${ }^{86} \mathrm{Rb}^{+}$ influx was confirmed (data not shown). We next used the patchclamp technique to study AChR activity electrophysiologically at the single-channel level. To record only ACh-activated channels, several other channel types present in these cells are blocked pharmacologically: $\mathrm{K}^{+}$channels are eliminated by adding tetraethylammoniumchloride (TEA) and removing $\mathrm{K}^{+}$from the medium; $\mathrm{Ca}^{2+}$ channels are eliminated by removing $\mathrm{Ca}^{2+}$ from the medium; and $\mathrm{Cl}^{-}$channels are blocked with $0.1 \mathrm{~mm}$ anthracene-9-carboxylic acid.

ACh induces bursts of AChR channel openings (Figs. 2, 3). At $0.5 \mu \mathrm{M}$ ACh the channels are open $3.3 \%$ of the time, whereas at $10 \mu \mathrm{M}$ ACh this increases to $8.8 \%$ (Fig. 2). Opening of TE671 AChR channels induced by ACh is blocked by $\alpha \mathrm{Bgt}$ (Fig. 3A). This is expected for muscle $A C h R s$ but not for neuronal nicotinic AChRs (reviewed in Lindstrom et al., 1988). TE671 AChR channels exhibit a linear current-voltage relationship in the range 10-100 $\mathrm{mV}$ (Fig. 3B) with a single-channel conductance $(\gamma)$ of 44-45 pS (Fig. 2). The majority of channel openings are brief $(65 \%$ have a time constant $[\tau]$ of $0.82 \mathrm{msec})$, whereas a minority of the openings are more prolonged (for $35 \% \tau=3.3 \mathrm{msec}$ ) (Fig. $3 C$ ). The duration of opening and magnitude of conductance are not affected by the concentration of $\mathrm{ACh}$ in the range 0.5 $20 \mu \mathrm{M}$ or by voltage in the range $50-100 \mathrm{mV}$. These properties are all consistent with those of muscle AChRs (Neher and Sakmann, 1976). Blockage of function by $\alpha \mathrm{Bgt}$ is the critical characteristic distinguishing AChRs on TE671 from those on neurons, since other electrophysiological properties are similar for neuronal AChRs which do not bind $\alpha$ Bgt (Lipton et al., 1987). Sine (1988) has recently observed electrophysiological properties of AChRs from TE671 cells similar to those reported here, and he has characterized their pharmacology in more detail. $\mathrm{He}$ finds that AChRs in TE671 cells are similar in many respects to those from Torpedo electric organ or mouse $\mathrm{BC} 3 \mathrm{H}-1$ muscle cells but differ from these most prominently in having longer closed-channel times, slower desensitization onset and offset, symmetry in binding reversible nicotinic antagonists, and much more rapid dissociation of bound $\alpha \mathrm{Bgt}$.

AChRs at mature neuromuscular junctions typically have shorter open channel lifetimes and greater conductances than do extrajunctional AChRs (Schuetze and Role, 1987). Analysis of ACh-induced noise at human neuromuscular junctions suggested that $\tau=1.3 \mathrm{msec}$ (Cull-Candy et al., 1979; Albuquerque et al., 1981), whereas human myotubes in culture, which would be expected to have extrajunctional AChRs, exhibit $\tau=2.4$ msec at room temperature (Bevan et al, 1978; Adams and Bevan, 1985). The observation that TE671 AChRs exhibit $\tau=$ 0.82 and $3.3 \mathrm{msec}$ may suggest that the cells synthesize both junctional and extrajunctional forms of AChRs. However, AChRs from both Torpedo electric organ (Labarca et al., 1984, 1985) and muscle (Sine and Steinbach, 1984; Colquhoun and Sakmann, 1985) open into either a short- or long-duration state. 


\section{NOMARSKI FLUORESCENCE}

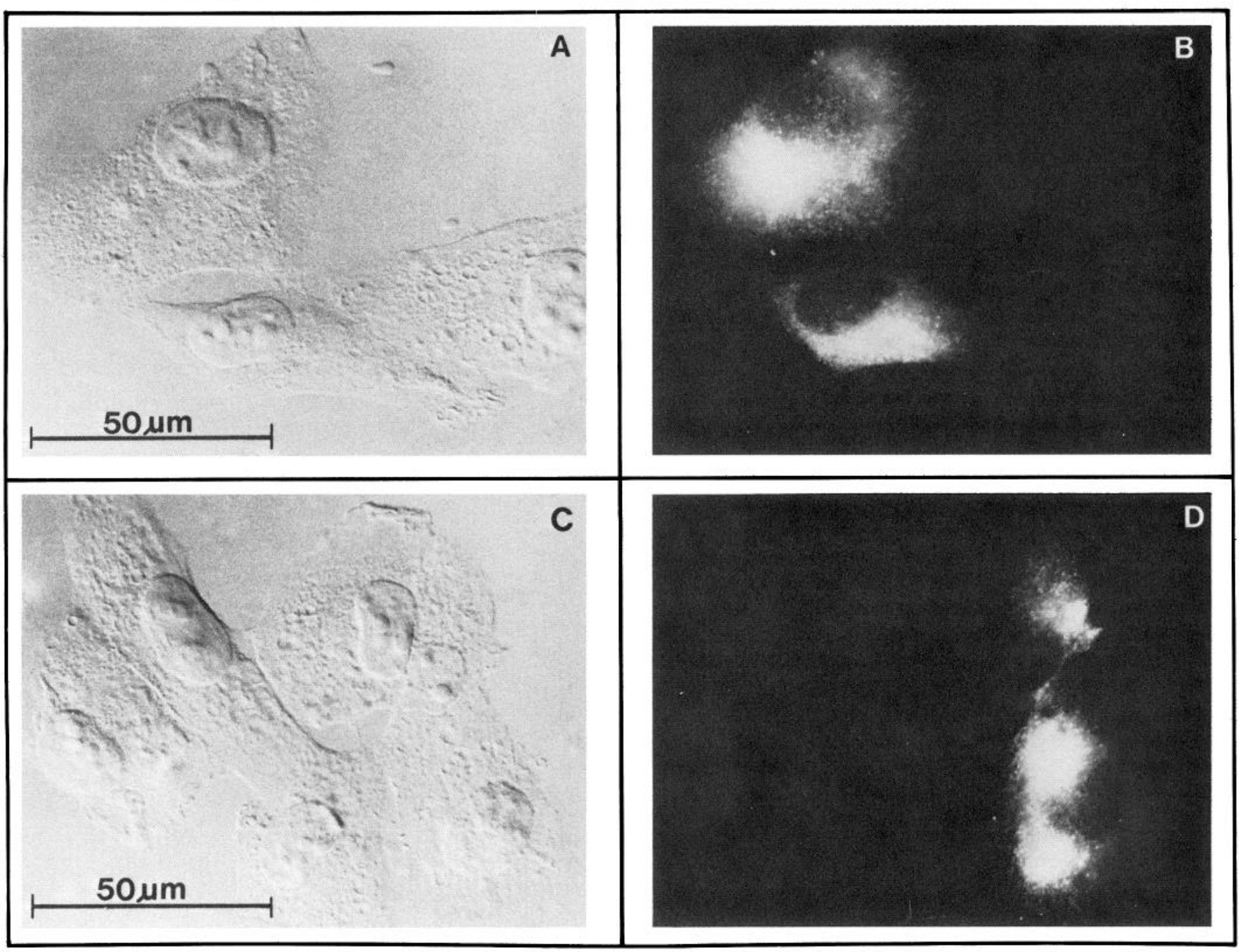

Figure 1. AChRs are not localized on the surface of all cells in a serum-starved TE671 culture. AChRs were labeled with mAb 210 , followed by rabbit anti-rat IgG, and then rhodamine-labeled goat anti-rabbit IgG. The same fields are examined in the pairs $A, B$ and $C, D$.

Junctional AChRs are thought to contain $\epsilon$ subunits instead of the $\gamma$ subunits characteristic of extrajunctional AChRs (Mishina et al., 1986; Witzemann et al., 1987). Determining whether the AChRs from TE671 cells are of the junctional or extrajunctional type is relevant not only to their electrophysiological properties and biochemical structure, but also to their antigenic structure, as some MG patient autoantibodies react exclusively with extrajunctional AChRs (Weinberg and Hall, 1979; Schuetze et al., 1985).

\section{AChRs on TE671 cells have the antigenic structure of extrajunctional muscle AChRs}

TE671 AChRs cross-react with antisera and mAbs specific for the 4 kinds of subunits in muscle AChR (Table 1). These data, in conjunction with the evidence that MG patient autoantibodies bind TE671 AChRs equally as well as muscle AChRs (Lindstrom et al., 1987a; Whiting et al., 1987), indicate that AChRs from TE671 cells appear to have the basic antigenic structure expected of human muscle AChRs.
The AChRs on TE671 cells are extrajunctional. This is shown by their ability to react with mAbs specific for extrajunctional AChRs. Two mouse mAbs, $\mathrm{C}_{9}$ and $\mathrm{F}_{8}$, raised against $\mathrm{AChR}$ from human muscle have previously been shown to react with AChRs extracted from human denervated or fetal muscle but not with junctional AChRs in sections of human muscle (Whiting et al., 1986). The titers of $m A b s C_{9}$ and $F_{8}$ are quite similar for AChRs extracted from the muscles of a leg amputated for diabetic neuropathy $\left(5.3 \times 10^{-4}\right.$ and $6.8 \times 10^{-5} \mathrm{M}$, respectively) and for AChRs extracted from TE671 cells $\left(6.8 \times 10^{-4}\right.$ and 8.3 $\times 10^{-5} \mathrm{M}$, respectively). This suggests that AChRs from TE671 cells should have $\gamma$ rather than $\epsilon$ subunits.

\section{AChRs purified from TE671 cells have the biochemical structure of muscle AChRs}

AChRs affinity-purified from TE671 cells on an $\alpha$ Bgt affinity column consist of 4 polypeptides corresponding to $\alpha, \beta, \gamma$, and $\delta$ subunits of $\mathrm{AChR}$ from Torpedo electric organ by apparent molecular weights $(42,000 ; 52,500 ; 55,000$; and 62,000$)$ 

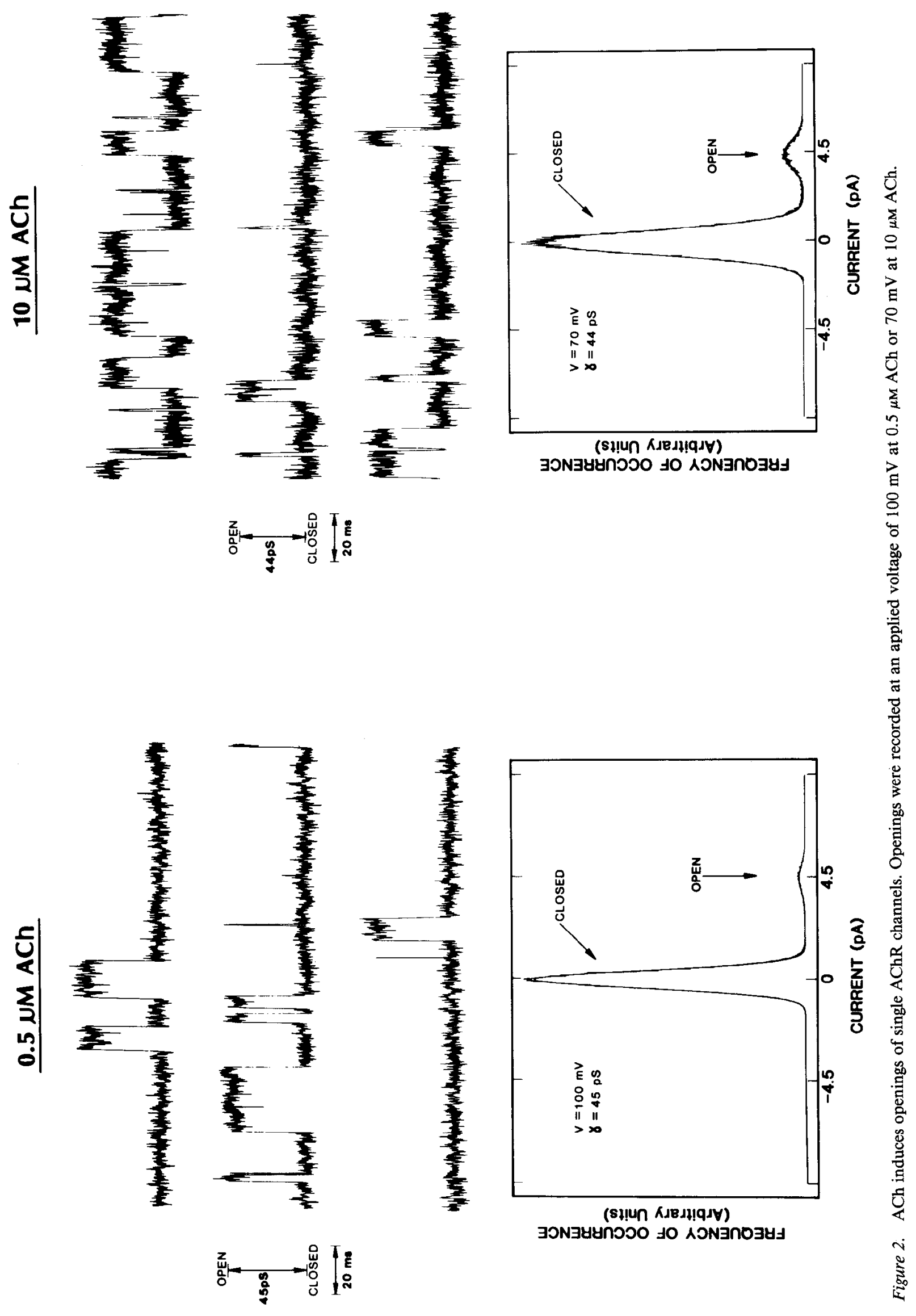

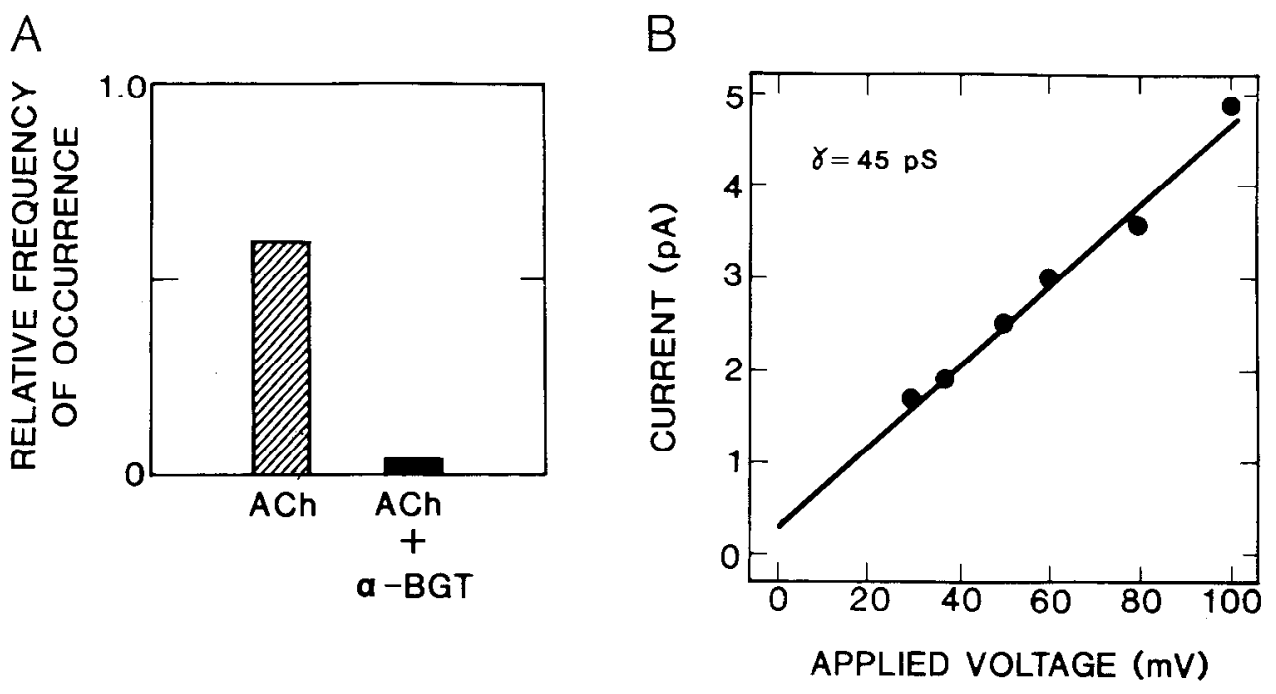

C

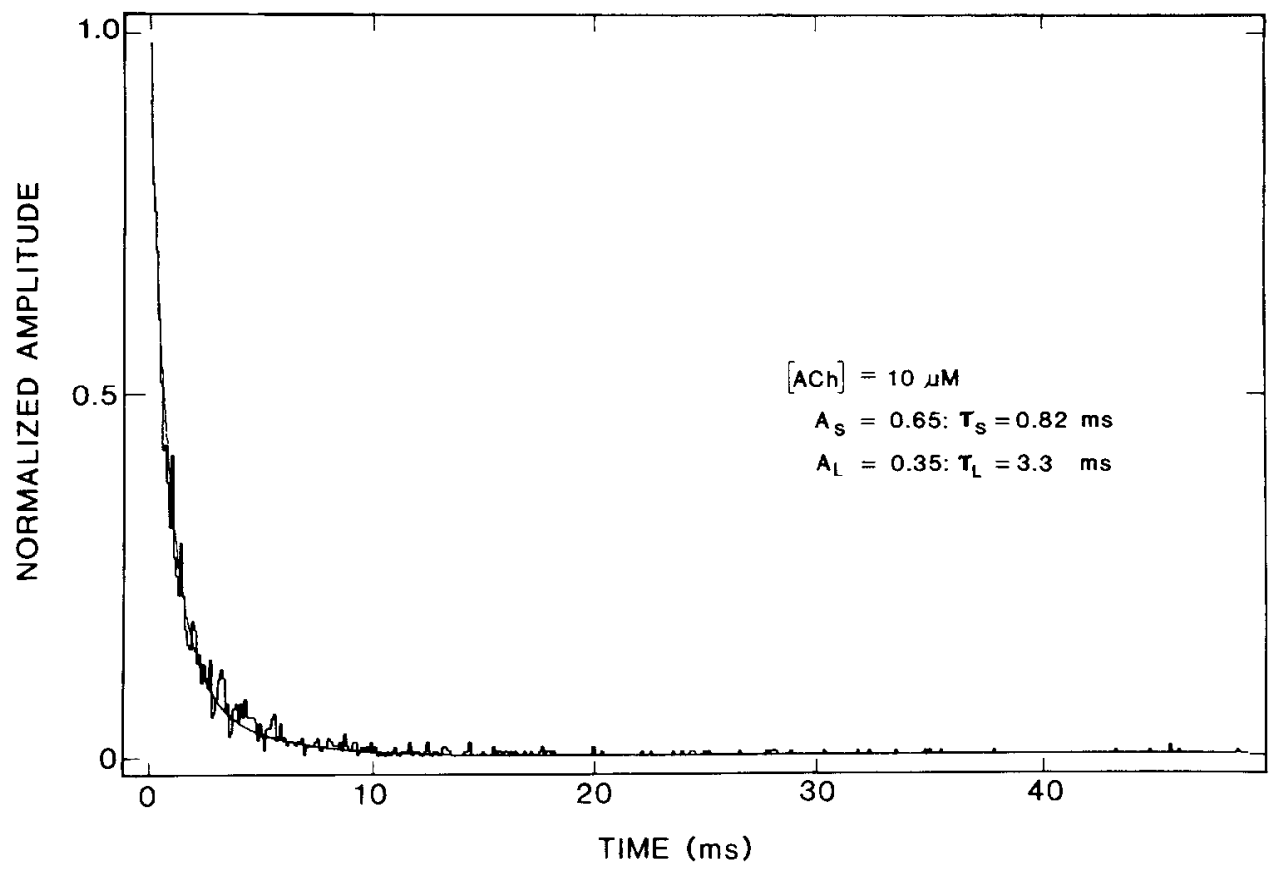

Figure 3. Analysis of single $\mathrm{AChR}$ channel currents. $A, \alpha$ Bgt blocks AChinduced channel openings. Results from several experiments are summed. $\mathrm{ACh}$ was used at $0.5-50 \mu \mathrm{M} . \alpha \mathrm{Bgt}$ was used at $0.04-0.15 \mu \mathrm{M}$. Membrane voltage was 70-100 mV. B, Linear current-voltage characteristics indicate ohmic channels. The slope conductance was $45 \mathrm{pS}$. $C$, Analysis of open-channel duration suggests that there are frequent short openings and less frequent longer openings. ACh was used at $10 \mu \mathrm{M}$ at a membrane potential of $100 \mathrm{mV}$. The data (noisy curve) were well fitted by a sum of 2 exponentials (smooth curve) $(p>$ 0.05 ). Total number of events analyzed, 2035.

(Fig. 4A) and also by antibody labeling on Western blots (Fig. $4 B)$. The ACh binding site is formed by $\alpha$ subunits, as shown by affinity labeling with 4-( $N$-maleimido)benzyltrimethylammoniumiodide (MBTA) (Fig. 4C), an agonist that specifically blocks ACh binding and labels cysteines 192,193 on the $\alpha$ subunit (Kao et al., 1984, 1986). A typical purification is reported in Table 2. AChRs are present in crude extracts at twice the specific activity reported for $\mathrm{BC} 3 \mathrm{H} 1$ cells (Boulter and Patrick, 1977) and can be purified at 3 times the yield. The specific activity of unpurified AChR from TE671 cells $(0.09 \mathrm{nmol} / \mathrm{gm}$ tissue) is $5 \%$ that of Torpedo electric organ and 27 times that of fetal calf muscle (Einarson et al., 1982). Immunoaffinity chromatography on mAb 210 yields a preparation of similar purity which is unable to bind $\alpha \mathrm{Bgt}$ efficiently due to the use of a denaturing rather than a competitive elution step.

AChRs are highly susceptible to proteolysis (Lindstrom et al., 1980), and prevention of proteolysis requires rigorous use of protease inhibitors, rapid preparation, and extensive washing.
AChR purified from human muscle by affinity chromatography using $\alpha \mathrm{Bgt}$ (Turnbull et al., 1985) or mAbs (Momoi and Lennon, 1982) has been reported to contain, respectively, 4 or 5 polypeptide chains of apparent molecular weights ranging from 44,000 to 66,000 . The 44,000-molecular-weight polypeptides are identified as $\alpha$ subunits by affinity labeling, but the other polypeptides are not identified. In these preparations, only AChR monomers are observed on sucrose gradients.

\section{Sequences of $c D N A$ s for the subunits of AChRs from TE671 show that these are muscle AChRs}

TE671 cells contain poly $A^{+}$mRNAs corresponding to the 4 kinds of subunits of muscle AChR detectable under high-stringency hybridization conditions with probes for the $\alpha, \beta, \gamma$, and $\delta$ subunits of AChR from mouse muscle (Fig. $4 D$ ). $\alpha$ Subunit mRNA is present in 3- to 5-fold higher concentration than the other subunit mRNAs.

The sequence of a cDNA for the $\alpha$ subunits of AChR from 


\begin{tabular}{|c|c|c|c|c|}
\hline \multirow[b]{2}{*}{$\begin{array}{l}\text { Speci- } \\
\text { ficity }\end{array}$} & \multirow[b]{2}{*}{ Immunogen } & \multirow[b]{2}{*}{$\mathrm{mAb}$} & \multicolumn{2}{|c|}{ Titer $(\mu \mathrm{M})$} \\
\hline & & & $\begin{array}{l}\text { Human } \\
\text { muscle }\end{array}$ & TE671 \\
\hline MIR & Human muscle $\mathrm{AChR}$ & 192 & 12.0 & 22.5 \\
\hline MIR & Human muscle $\mathrm{AChR}$ & 196 & 0.24 & 0.74 \\
\hline MIR, $\alpha$ & $\begin{array}{l}\mathrm{BC} 3 \mathrm{H} 1 \text { and fetal } \\
\text { bovine muscle }\end{array}$ & 210 & 7.1 & 7.0 \\
\hline $\operatorname{MIR}, \alpha$ & Human muscle $\mathrm{AChR}$ & 203 & 1.4 & 2.2 \\
\hline MIR, $\alpha$ & Human muscle $\mathrm{AChR}$ & 207 & 7.3 & 5.1 \\
\hline$\alpha$ & Torpedo $\alpha$ & Antisera & 0.005 & 0.008 \\
\hline$\beta$ & Torpedo $\beta$ & 111 & 0.70 & 1.2 \\
\hline$\beta$ & Torpedo $\beta$ & Antisera & 0.004 & 0.005 \\
\hline$\gamma$ & Bovine muscle AChR & 66 & 0.89 & 0.72 \\
\hline$\gamma$ & Torpedo $\gamma$ & Antisera & 0.0015 & 0.001 \\
\hline$\delta$ & Torpedo $\delta$ & 137 & 0.52 & 0.74 \\
\hline$\delta$ & Torpedo $\delta$ & Antisera & 0.002 & 0.001 \\
\hline
\end{tabular}

TE671 (Fig. 5; Schoepfer et al., 1988) is identical to that expected from a human genomic clone (Noda et al., 1983a). It exhibits 97\% sequence identity with $\alpha$ subunits from bovine muscle (Noda et al, 1983a), 95\% sequence identity with $\alpha$ subunits from mouse (Boulter et al., 1985), 82\% identity with $\alpha$ subunit for Xenopus (Baldwin et al., 1988), and $81 \%$ identity with $\alpha$ subunits from Torpedo (Noda et al., 1982). In particular, $\alpha$ subunits from TE671 resemble those from other species in exhibiting 4 hydrophobic sequences, an $\mathrm{N}$-glycosylation site, and cysteines at positions 192,193, which, in the case of Torpedo, have been shown to react with affinity-labeling reagents for the ACh binding site (Kao et al., 1984).

The sequence of a cDNA for the $\delta$ subunits of AChR from TE671 is that also expected for $\delta$ subunits of muscle AChRs (Figs. 6, 7). Comparison of the amino acid sequence of TE671 AChR $\delta$ with that of $\delta$ subunits from other species reveals $91 \%$ identity to calf (Kubo et al., 1985), 90\% identity to mouse (La Polla et al., 1984), 72\% identity to chicken (Nef et al., 1984), $68 \%$ identity to Xenopus (Baldwin et al., 1988), and $61 \%$ to Torpedo (Noda et al., 1983c). It exhibits $30 \%$ sequence identity in the mature protein to $\alpha$ subunits from TE671 (Schoepfer et al., 1988), showing that the subunits forming the AChR are homologous, as expected from previous studies (Raftery et al., 1980; Noda et al., 1983b). In comparison with $\delta$ subunits of other species, the $\delta$ subunits from TE671 show conservation of 4 hydrophobic sequences, 3 putative $\mathrm{N}$-glycosylation sites, and 3 putative phosphorylation sitcs. Likc $\delta$ subunits from muscle of other species, $\delta$ subunits from TE671 lack a cysteine penultimate to the C-terminus found in $\delta$ subunits of AChRs from Torpedo electric organ (Noda et al., 1983c). It is suspected that AChR dimers from Torpedo are formed by a disulfide bond between the $\delta$ subunits of adjacent AChR monomers which involves this penultimate cysteine (Wennogle et al., 1981; Noda et al., 1983c).

\section{Expression of AChR in TE671 cells can be regulated by neurotransmitters, hormones, and neurotrophic factors}

Treatment of TE671 cells with nicotine, dexamethasone, or hCGRP results in an increase in the observed $\alpha$ Bgt binding to AChRs on the cell's surface (Fig. 8). Nicotine and dexamethasone result in an elevation in the number of functional AChRs, while only dexamethasone causes an increase in the amounts of most AChR subunit RNAs. Curiously, although hCGRP upregulates $\alpha \mathrm{Bgt}$ binding, $\mathrm{AChR}$ function is reduced. It is apparent that regulation of AChRs in TE671 cells appears to occur by more than one mechanism. Both transcriptional regulation of synthesis (in the case of dexamethasone) and other mechanisms (in the cases of nicotine and hCGRP) seem to be involved.

The means by which AChR synthesis is regulated in TE671 cells and in muscle cells may differ because, whereas nicotine up-regulates the amount of AChR in $1 \mathrm{E} 671$ cells, agonists downregulate the number of AChR in muscle cells (Ashizawa et al., 1982). We have observed that agonists up-rcgulate the amount of ganglionic-type AChR in the rat PC12 cell line (P. Whiting and J. Lindstrom, unpublished observations), whereas in chicken ciliary ganglion cultures agonists down-regulate the number of AChRs (Smith et al., 1986). Thus, mechanisms of AChR regulation may vary greatly in different cell types. For example, it is possible that in TE671 the AChR is under a "neuronal" type of regulation that may differ from that observed in muscle. Interestingly, the nonfusing mouse muscle-like cell line $\mathrm{BC} 3 \mathrm{H} 1$, like TE671, was also obtained from the CNS (Schubert et al., 1974) but exhibits muscle-like regulation. In ciliary ganglion cells, growth conditions can also alter the ratio of functional to nonfunctional AChRs in the surface membrane (Margiotta et al., 1987). Similarly, in TE671 cells, hCGRP seems to increase the total number of AChRs while decreasing the number of functional AChRs. These preliminary observations on the regulation of AChR expression in TE671 cells merit more detailed study. The effects of CGRP are especially interesting in view of its postulated role as a neurotrophic factor in chicken myotubes, where it increases both AChR $\alpha$ subunit mRNA and AChR protein, perhaps via an increase in cyclic AMP concentration (Fontaine et al., 1986, 1987).

Forskolin, an adenylate cyclase activator (Seaman et al., 1981), is reported to induce AChR phosphorylation (Grassi et al., 1987;

Table 2. Purification of AChR from $20 \mathrm{gm}$ (12 roller bottles) of TE671 cells

\begin{tabular}{lcllll} 
& & & & & \multicolumn{2}{l}{$\begin{array}{l}\text { 125I- } \alpha \text { Bgt } \\
\text { specific } \\
\text { activity } \\
\text { (pmol/mg } \\
\text { protein) }\end{array}$} \\
\hline Initial extract & $\begin{array}{l}\text { Volume } \\
(\mathrm{ml})\end{array}$ & $\begin{array}{l}\text { Protein } \\
(\mathrm{mg})\end{array}$ & pmol & $\%$ & 3.16 \\
Unbound to $\alpha$ Bgt affinity column & 100 & 570 & 1804 & 100 & - \\
Wash steps & 100 & 380 & 702 & 39 & - \\
Affinity column eluate & 650 & 180 & 342 & 19 & - \\
\hline
\end{tabular}




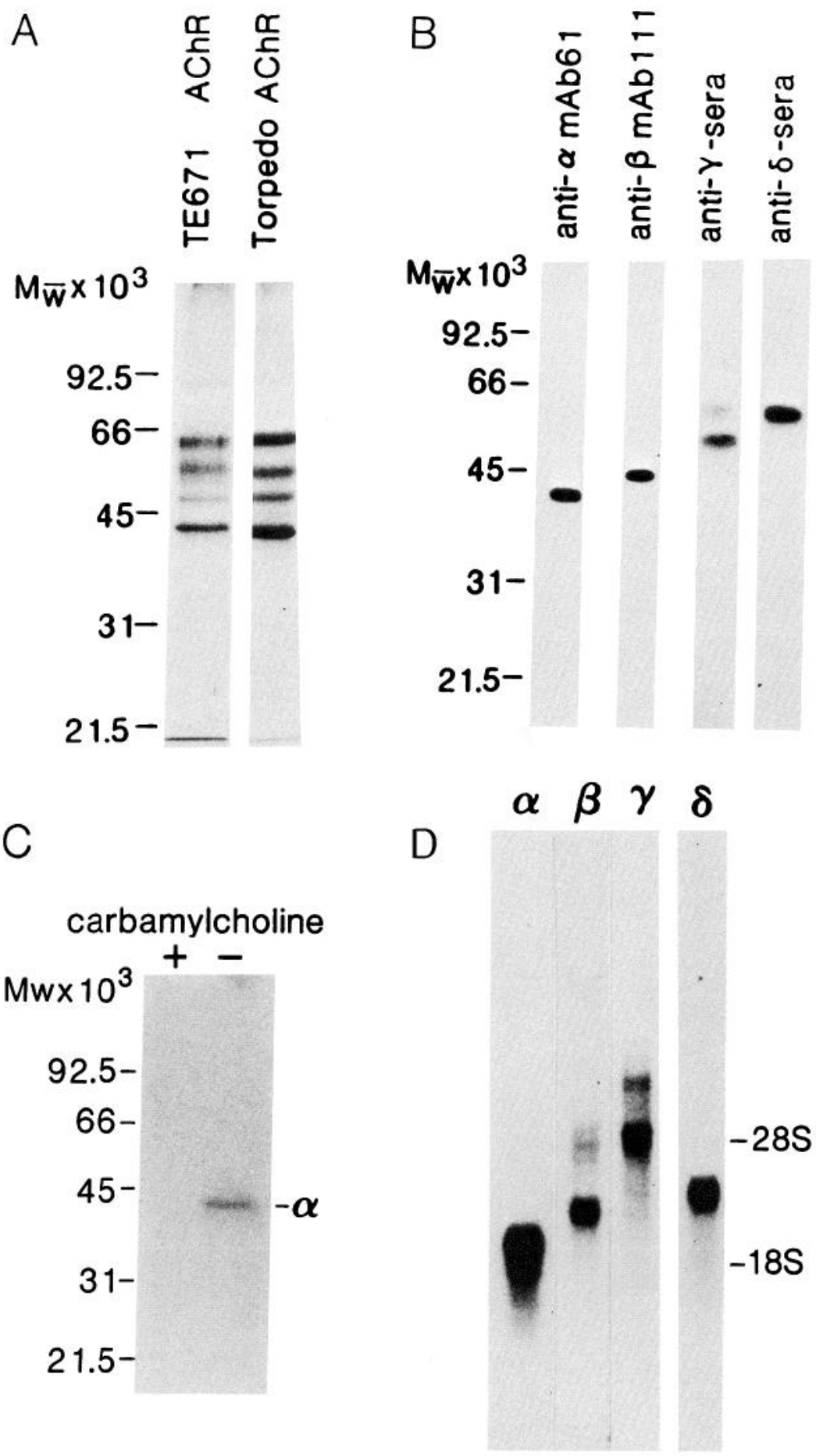

Figure 4. Subunits of AChRs trom TE671. A, AChRs affinity-purified from TE671 and Torpedo eletric organ have similar subunits. AChRs $(10 \mu \mathrm{g})$ were resolved into their subunits by electrophoresis on a $10 \%$ acrylamide gel in SDS under reducing conditions and stained with Coomassie blue. $B$, Subunits from TE671 AChRs correspond to those of electric organ AChRs by Western blotting. Purified TE671 AChR ( $50 \mathrm{ng} / \mathrm{lane})$ was resolved into subunits by electrophoresis and then blotted onto DPT paper. Each lane was incubated with the indicated antibody, mAb 61 (Tzartos et al., 1981) and mAb 111 (Tzartos et al., 1986) at $10 \mathrm{nM}$, and $\gamma$ and $\delta$ anti-subunit sera (Lindstrom et al., 1979) at $1 \mathrm{~nm}$. Bound antibodies were localized by autoradiography using ${ }^{125}$ I mouse anti-rat IgG. $C$, Affinity labeling with ${ }^{3} \mathrm{H}-\mathrm{MBTA}$ identifies the $\alpha$ subunits of AChR from TE671 as forming the ACh binding site. $D$, Poly $A^{+}$mRNAs for the 4 subunits of TE671 $\mathrm{AChR}$ are detected by high-stringency hybridization with cDNAs for mouse muscle AChR $\alpha, \beta, \gamma$, and $\delta$ subunits. The cDNA probes used were described by Heinemann et al. (1986).
Miles et al., 1987; Smith et al., 1987) and to enhance AChR desensitization (Albuquerque et al., 1986; Huganir et al., 1986; Middleton et al., 1986). Treatment of TE671 cells with forskolin causes a decrease in the number of functional AChRs to background levels, which is accounted for by the reduction of $\alpha \mathrm{Bgt}$ binding and AChR subunit mRNAs (Fig. 8). Forskolin also appears to inhibit cell division and result in the formation of extensive neuron-like projections (Fig. 9). This effect, however, is reversible. These results suggest that if the effects of forskolin are mediated by an elevation in cAMP concentration, then the increase in AChR induced by hCGRP in TE671 must not be mediated by increased cAMP and may involve some other second messenger. However, a recent report by Wagoner and Pallotta (1988) indicates that although forskolin may stimulate cAMP-dependent phosphorylation in intact muscle and facilitate AChR desensitization, nonetheless, in intact muscle cAMP-dependent phosphorylation does not modulate desensitization. cAMP-induced phosphorylation and desensitization of AChRs could explain the lower number of active AChRs on the surface of hCGRP-treated TE671 cells. Forskolin treatment of TE671 cells does not induce synthesis of neuronal nicotinic AChRs since treated cells do not bind ${ }^{3} \mathrm{H}$-nicotine with high 


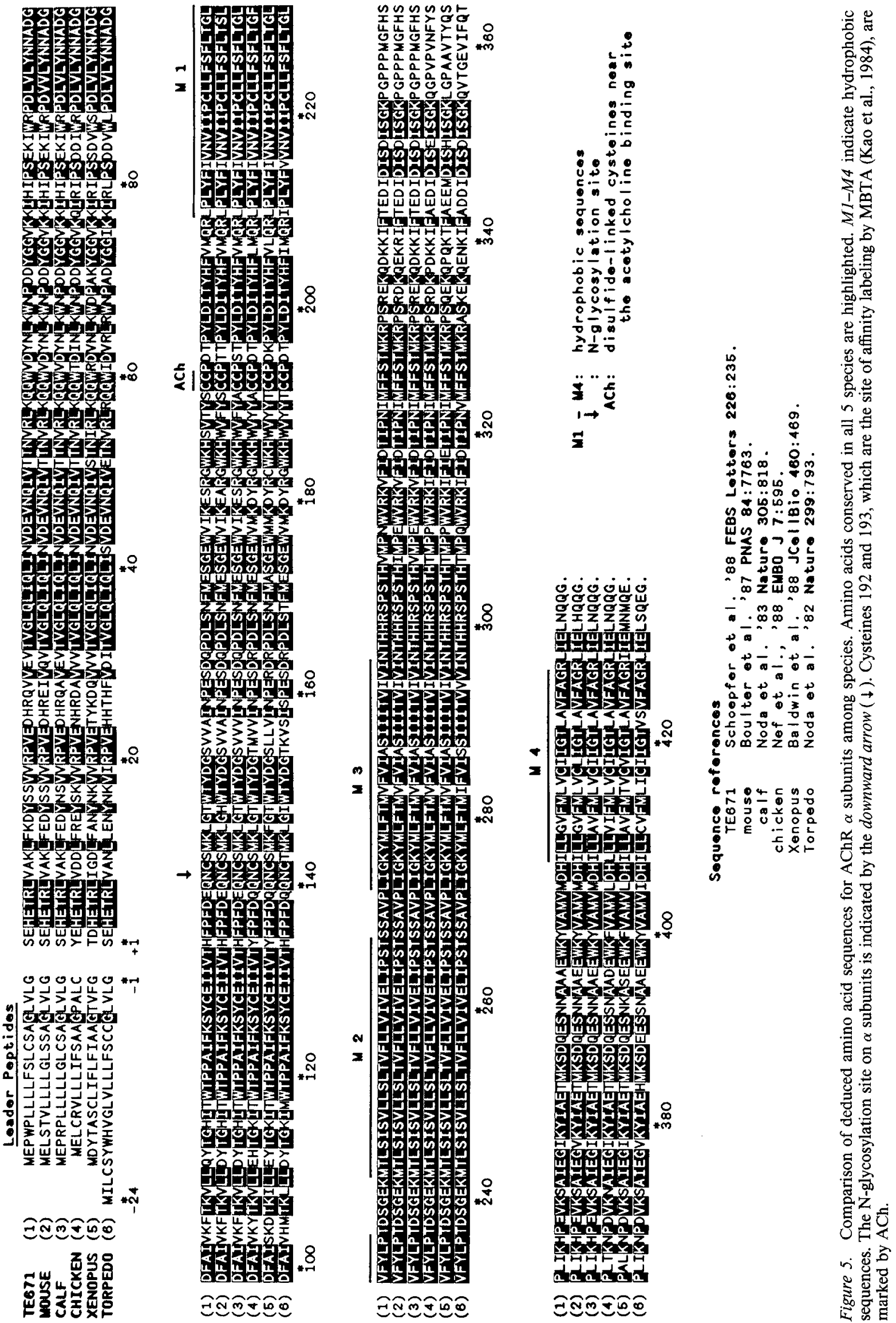




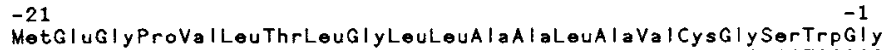 . TGGGATGGAGGGGCCAGTGCTGACACTGGGGCTGCTGGCTGCCCTGGCGGTGTGTGGCAGCTGGGGG
$-6 B$
$-40$
$-20$

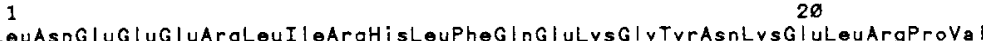

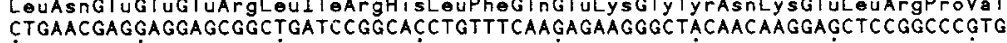
i $2 \varnothing$ $4 \dot{\varnothing}$

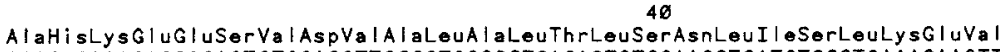
60 GCACACAAAGAGGAGAGTGTGGACGTTGCCCTGGCCCTCACACTCTCCAACCTCATCTCCCTGAAAGAAGTT $8 \varnothing$ 100 80

120 140

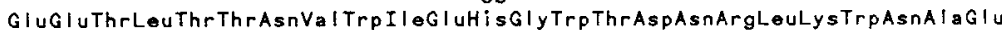
GAGGAGACCCTCACTACCAATGTGTGGATAGAGCACGGCTGGACAGACAACCGGCTGAAGTGGAATGCTGAA 160

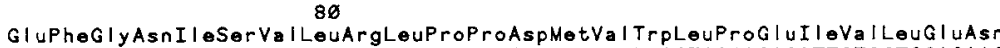
$18 \dot{0}$ $20 \dot{0}$ GAA I TTGAAACATCAGTGTCCTGCGCCTCCCCCCGGACATGGTGTGGCTCCCAGAGATTGTGCTGGAGAAC 220

$$
240
$$$$
268
$$$$
280
$$

100 260

120

AsnAsnAsp G Y SerPheg InI loSorTyrSerCysAsnValLeuVaITyrHisTyrGIyPheValTyrTro AACAATGACGGCTCCTTCCAGATCTCCTACTCCTGCAACGTGCTTGTCTACCACTACGGCTTCGTGTACTGG 300 320 $34 \dot{0}$ 140 LouProProAlaI I PhoArgSerSerCysProI leSerValThrTyrPheProPheAspTrpGInAsnCys
CTGCCACCTGCCATCTTCCGCTCCTCCTGCCCCATCTCTGTCACCTATTTCCCCTTCGACTGCAGAACTGC 380 400

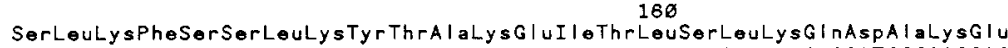

420 TCCCTCAAGTTCAGTTCCCTCAAGTATACGGCCAAAGAGATCACCCTGAGCCTGAARCSAGGATGCCAAGGAG 440 460 480

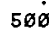

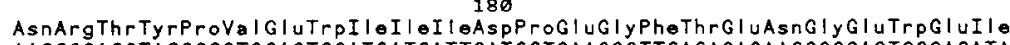
AACCGCACCTACCCCGTGGAGTGGATCATCATTGATCCTGAAGGCTTCACAGAGAACGGGGAGTGGGAGATA 520 200

$$
54 \dot{0}
$$$$
660^{\circ}
$$

ValHisArgProA laArgVa|AsnVa|AspProArgAl aProLouAspSerProSorArgGInAspI leThr GTCCACCGGCCGGCCAGGGTCAACGTGGACCCCAGAGCCCCTCTGGACAGCCCCAGCCGCCAGGACATCACC 580 600

$$
620
$$

640

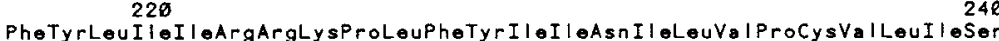
TTCTACCTCATCATCCGCCGCAAGCCCCTCTTCTACATCATCAACATCCTGGTGCCCTGCGTGCTCATCTCC BBO 68 700

260 720

PheMetVa I AsnLouVa\$heTyrLouProAlaAspSerGIyGIULysThrSerVaIAI I I OSORVaILou TTCATGGTCAACCTGGTCTT CTACCTACCGGCTGACAGTGGTGAGAAGACATCAGTGGCCATCTCGGTGCTC 740 780

280 780

LeuA I a I InServa IPhoLouLouLeuI I OSerLysArgLouProA I ThrSorMetA I a I oProLeuI Ie CTGGCTCAGTCTGTCTTCCTGCTGCTCATCTCCAAGCGTCTGCCTGCCACATCCATGGCCATCCCCCTTATC $8 \varnothing \dot{\sigma}$ 820 $\mathbf{8 4 6}$ 866

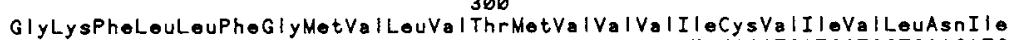
GGCAAGTTCCTGCTCTTCGGCATGGTGCTGGTCACCATGGTTGTGGTGATCTGTGTCATCGTGCTCAACATC 880 328 900 920

Hi sPhoArgThrProSerThrH IsVaILouSerGIUGI yVaILysLysLouPhoLouGI UThrLeuProGI U CACTTCCGAACACCCAGCACCCATGTGCTGTCTGAGGGGGTCAAGAAGCTCTTCCTGGAGACCCTGCCGGAG $94 \dot{0}$ 960 $980^{\circ}$ 1900

OUL 340 UH CTCCTGCACATGTCCCGCCCAGCAGAGGATGGACCCAGCCCTGGGGCCCTGGTGCGGAGGAGCAGCTCCCTG 1920 $104 \varnothing$ 1880 380 1680

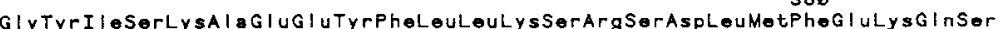
GGATACATCTCCAAGGCCGAGGAGTACTTCCTGCTCAAGTCCCGCAGTGACCTCATGTTCGAGAAGCAGTCA $110 \dot{0}$ 1120 $114 \dot{\emptyset}$

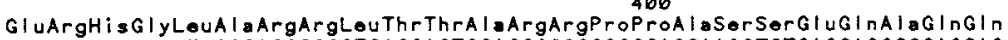
GAGCGGCATGGGCTGGCCAGGC GCCTCACCACTGCACGCCGGCCCCCAGCAAGCTCTGAGCAGGCCCAGCAG 1180 1180 420

$$
1200
$$

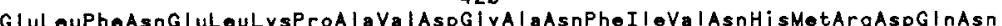
GAACTC̣TTCAATGAGCTGAAGCCGGCTGTGGATGGGGCAAACTTCATTGTTAACCACATGAGGGACCAGAAC 1240 446 $128 \dot{0}$ 1280

AsnTyrAsnGI UGI ULYsAspSerTrpAsnArgVa IAlaArgThrValAspArgLouCysLouPheValVaI AATTACAAT GAGGAGAAAGACAGCTGGAACCGAGTGGCCCGCACAGTGGACCGCCTCTGCCTGTTTGTGGTG 1300 1320 1340 1389

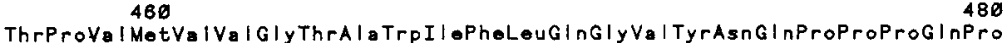
ACGCCTGTCATGGTGGTGGGCACAGCCTGGATCTTCCTGCAGGGCGTTIACAACCAGCCACCACCCCAGCC! $\begin{array}{llll}1380 & 1400 & 1420 & 1440\end{array}$

PheProglyAspProTyrSorTyrAsnVa IG I nAspLysArgPheI lo TTTCCTGGGGACCCCTACTCCTACAACGTGCAGGACAAGCGCTTCATCTAGGGTGGGCCTGTTGGGGAGCCA 1480 1480 1560 GGAGACAGCAGGGTCTGAGAGAGGAGCCACAGTCCCTẠATGACACCCACTCCTAGCCC̣TGAGGCTCGTGCCC 1620 1540 1580 1580

CTCAGACTGGgGAaGAGTCCAAGGAaGGGAGGGAGCAGCCACTCCTCAATGCTCAATGGCTCCCCTGAAATC 16 16ஜ 1620 1848

AAGACAGGGGCCACCCGAGG..... 1680
Figure 6. Nucleotide sequence and deduced amino acid sequence of a TE671 cDNA clone coding for the AChR $\delta$ subunit. The mature protein starts at position +1 . The cDNA clone 6.4 untranslated region extends $124 \mathrm{nu}$ cleotides further upstream. This portion of the sequence contains unrelated sequences revealed by Northern blot analysis (data not shown). 


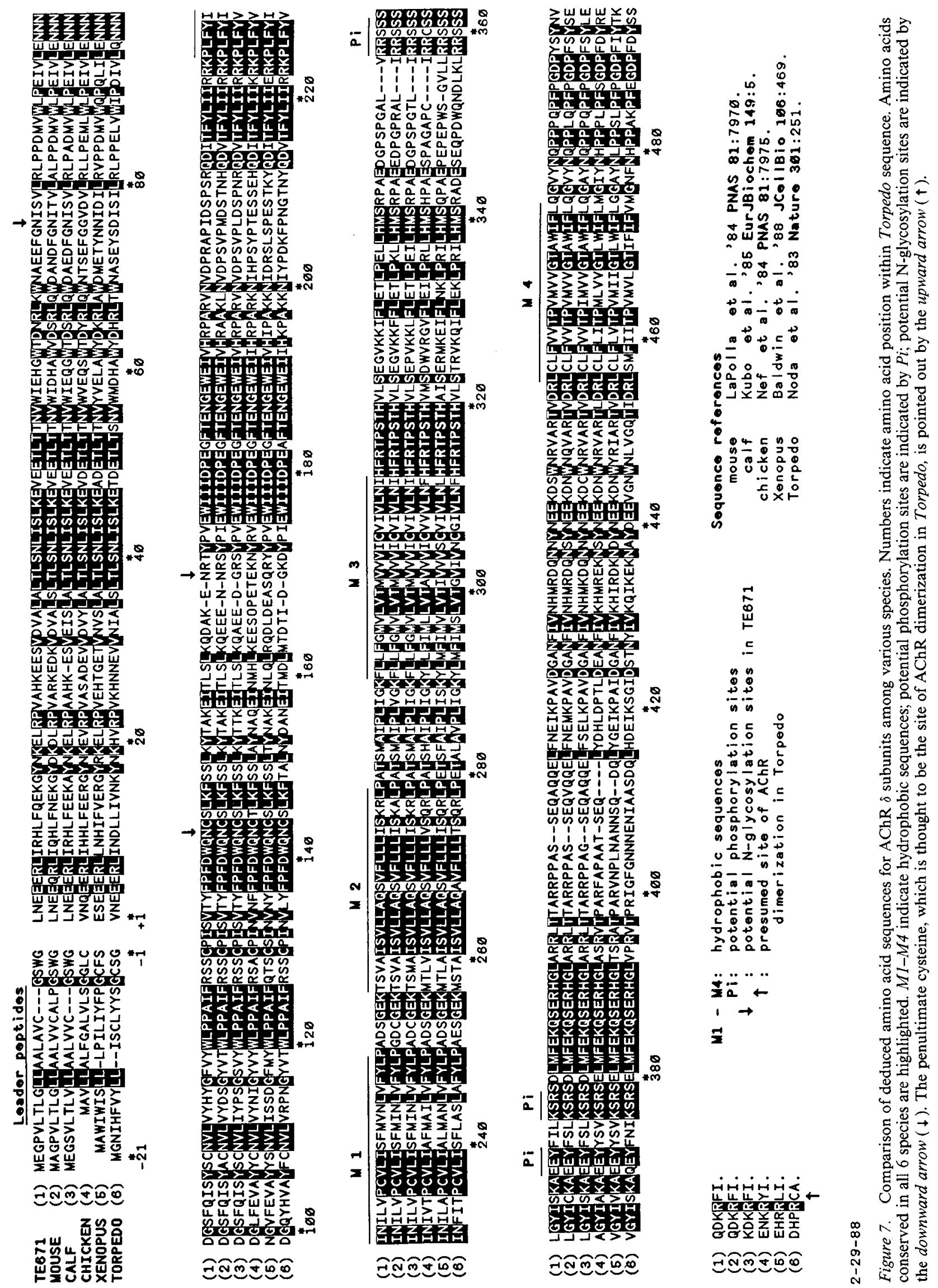




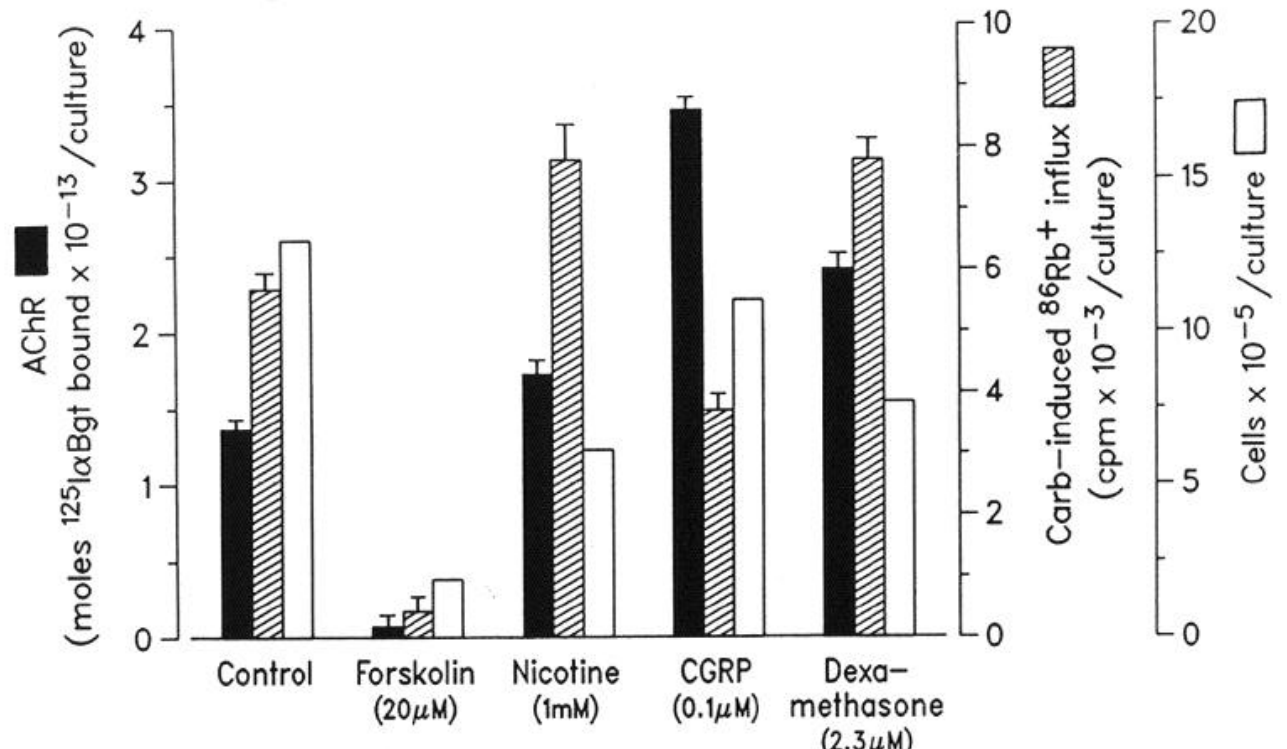

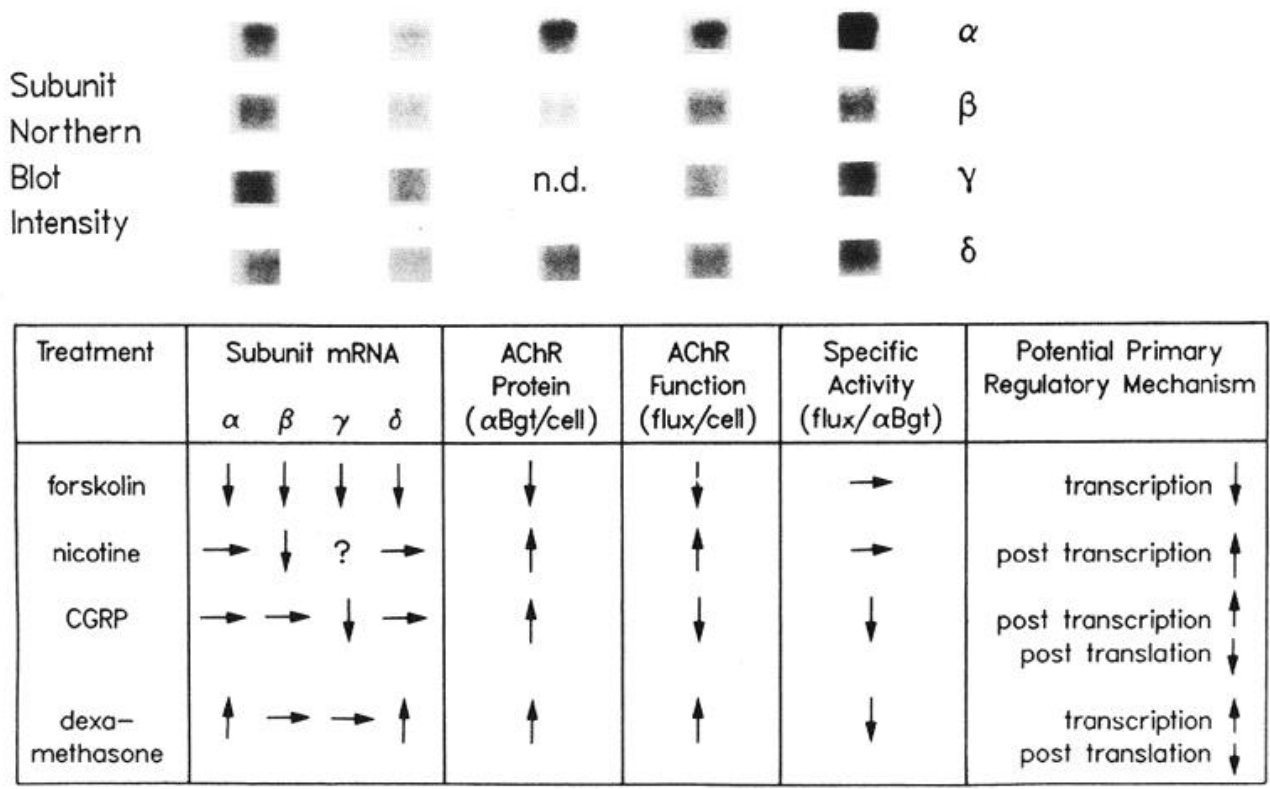

Figure 8. Nicotine, dexamethasone, CGRP, and forskolin affect AChR expression in TE671 cells. First, $1 \times$ $10^{5}$ cells were plated in each $3.5 \mathrm{~cm}$ dish on day 0 . On day 2 , media was supplemented as indicated. On day 4, carbamylcholine-induced ${ }^{86} \mathrm{Rb}^{+}$influx was measured on sister triplicate cultures. Background was determined for each culture conditions and subtracted to give the values shown (average background, $500 \mathrm{cpm}$ ). Northern blots using equal amounts of total RNA from other sister cultures were probed successively with ${ }^{32} \mathrm{P}$-labeled mouse $\alpha$, mouse $\beta$, mouse $\gamma$, and human $\delta$ cDNAs. ${ }^{125} \mathrm{I}-\alpha$ Bgt binding to cell surfaces was measured in a series of cultures. affinity or mAbs specific for human brain AChRs. Also, hybridization signals are not detected when northern blots of TE671 RNA are hybridized at high stringency with the cDNA probe $\alpha 4$ (Goldman et al., 1987); this probe codes for the AChbinding subunit of the $\mathrm{AChR}$ from rat brain, which has high affinity for nicotine. It is possible that forskolin may induce the synthesis of some other neuronal receptors or AChRs, but these have not yet been detected.

\section{Concluding remarks}

We have proven that extrajunctional muscle-like AChRs are expressed in relatively large amounts by the human neuronal cell line TE671. This cell line is a valuable system for studying the structure of human muscle AChR. AChR expression in these cells can be regulated by several factors, which can be employed to study in detail the mechanisms regulating $\mathrm{AChR}$ expression in TE671 cells.

This cell line may prove valuable for studies of MG because (1) it provides a much larger and more uniform source of human
AChR for use in diagnostic immunoassays than does amputated leg muscle; (2) it can be used more effectively to study antigenic modulation or inhibition of AChR function by MG autoantibodies than can primary cultures of human fetal muscle (which are difficult to obtain) or rodent muscle cell lines (which crossreact poorly); and (3) it is a good source of human muscle AChR subunit cDNAs, which in suitable expression systems may prove valuable for mapping the antigenic structure of human AChR and providing antigen for studies of specific immunosuppression of MG.

Why should muscle-like AChRs be expressed in a neuronal cell line? We have considered 3 possibilities. First, expression of muscle AChR may be an aberration induced by the transformation events that produced this tumor line. Second, TE671 cells may be derived from a neuronal cell type that transiently expresses muscle-like AChRs during development. This would explain why muscle-like AChRs are not detected in extracts of adult human brains, and one could imagine that some developmental inducer could normally affect the development of this 


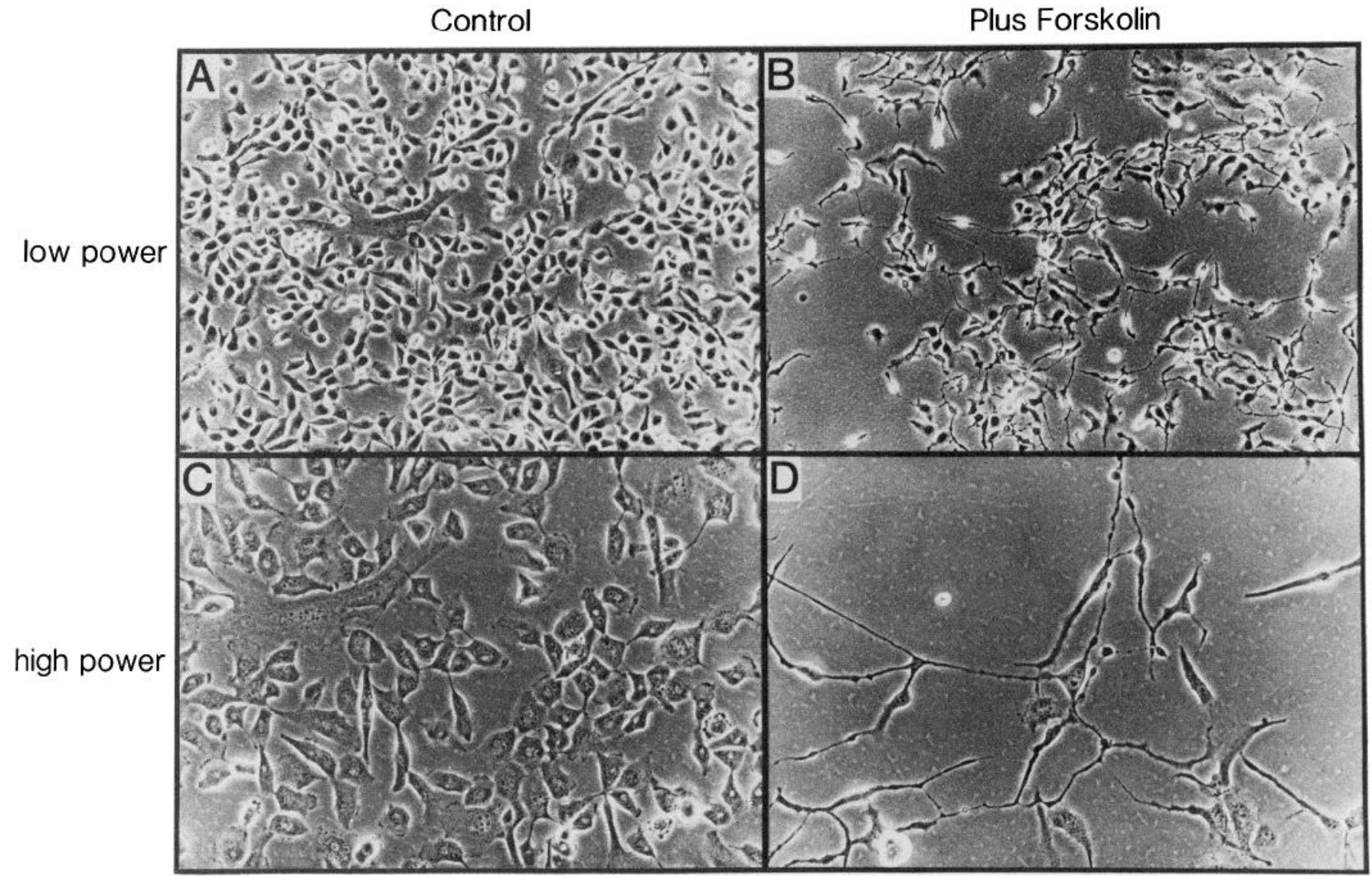

Figure 9. Forskolin affects cell division and morphology of TE671 cells. Equal amounts of cells were grown for $48 \mathrm{hr}$ in Iscove's medium plus $5 \%$ fetal bovine serum plus $(B, D)$ or minus $(A, C) 20 \mu \mathrm{M}$ forskolin. Note that in the presence of forskolin, cell density is reduced and extension of processes by the cells is greatly increased.

neuronal cell type in the same way that forskolin affects TE671 cells, terminating AChR synthesis and cell division. And third, TE671 cells may be derived from a cell type normally present in adult cerebellum. In this case, to escape detection in brain extracts the amount of muscle-like AChRs expressed on these cells would have to comprise a very small fraction of the total $\alpha$ Bgt-binding proteins in the brain. This is a possibility. Interestingly, it has been reported that there are interneurons in rat cerebellar cortex with AChRs that can be activated by nicotine and blocked by $\alpha$ Bgt (De la Garza et al., 1987).

Note added in proof: Stratton et al. (1989) have recently reported several lines of evidence suggesting that TE671 was misidentified when initially reported by McAllister et al. (1977), and that it is in fact identical to the rhabdomyosarcoma cell line RD, previously reported by McAllister et al. (1969). This would explain the presence of muscle AChR.

\section{References}

Adams, D., and S. Bevan (1985) Some properties of acetylcholine receptors in human cultured myotubes. Proc. R. Soc. London [Biol.] 224: 183-196.

Albuquerque, E., J. Warnick, R. Mayer, A. Eldefrawi, and M. Eldefrawi (1981) Recent advances in the molecular mechanisms of human and animal models of myasthenia gravis. Ann. NY Acad. Sci. 377: 496518.

Albuquerque, E., S. Deshpande, V. Aracawa, M. Alkondon, and J. Daly (1986) A possible involvement of cyclic AMP in the expression of desensitization of the nicotinic acetylcholine receptor. A study with forskolin and its analogs. FEBS Lett. 199: 113-120.
Ashizawa, T., S. Elias, and S. Appel (1982) Interaction of myasthenic immunoglobulins and cholinergic agonists on acetylcholine receptors of rat myotubes. Ann. Neurol. 11: 22-27.

Baldwin, T., C. Yashihara, K. Blackmer, C. Kintner, and S. Burden (1988) Regulation of acetylcholine receptor transcript expression during development in Xenopus laevis. J. Cell Biol. 106: 469-478.

Bevan, S., R. Kullberg, and J. Rice (1978) Acetylcholine-induced conductance fluctuations in cultured human myotubes. Nature 273: 469470.

Boulter, J., and J. Patrick (1977) Purification of an acetylcholine receptor from a nonfusing muscle cell line. Biochemistry 16: 49004908.

Boulter, J., W. Luyten, K. Evans, P. Mason, M. Ballivet, D. Goldman, S. Stengelin, G. Martin, S. Heinemann, and J. Patrick (1985) Isolation of a clone coding for the $\alpha$ subunit of a mouse acetylcholine receptor. J. Neurosci. 5: 2545-2552.

Chirgwin, J., A. Pryzbyla, R. MacDonald, and W. Rutter (1979) Isolation of a biologically active ribonucleic acid from sources enriched in ribonuclease. Biochemistry 18: 5294-5299.

Colquhoun, D., and B. Sakmann (1985) Fast events in single channel currents activated by acetylcholine and its analogues at the frog muscle end plate. J. Physiol. (Lond.) 369: 501-557.

Cull-Candy, S., R. Miledi, and A. Trautmann (1979) End plate currents and acetylcholine noise at normal and myasthenia end plates. J. Physiol. (Lond.) 287: 247-265.

De la Garza, R., T. J. McGuire, R. Freedman, and B. J. Hoffer (1987) Selective antagonism of nicotine actions in the rat cerebellum with $\alpha$ Bungarotoxin. Neuroscience 23: 887-891.

Einarson, B., W. Gullick, B. Conti-Tronconi, and J. Lindstrom (1982) Subunit composition of fetal calf muscle nicotinic acetylcholine receptor. Biochemistry 21: 5295-5302.

Fontaine, B., A. Klarsfeld, T. Hökfelt, and J.-P. Changeux (1986) Cal- 
citonin gene-related peptide, a peptide present in spinal cord motor neurons, increases the number of acetylcholine receptors in primary cultures of chick embryo myotubes. Neurosci. Lett. 71: 59-65.

Fontaine, B., A. Klarsfeld, and J.-P. Changeux (1987) Calcitonin generelated peptide and muscle activity regulate acetylcholine receptor $\alpha$-subunit mRNA levels by distinct intracellular pathways. J. Cell Biol. 105: 1337-1342.

Goldman, D., E. Deneris, W. Luyten, A. Kochar, J. Patrick, and S. Heinemann (1987) Members of a nicotinic acetylcholine receptor gene family are expressed in different regions of the mammalian central nervous system. Cell 48: 965-973.

Grassi, F., L. Monaco, and F. Eusebi (1987) Acetylcholine receptor channel properties in rat myotubes exposed to forskolin. Biochem. Biophys. Res. Commun. 147: 1000-1007.

Gullick, W., and J. Lindstrom (1982) The antigenic structure of the acetylcholine receptor from Torpedo californica. J. Cell. Biochem. 19: 223-230.

Heinemann, S., J. Boulter, J. Connolly, D. Goldman, K. Evans, D. Treco, M. Ballivet, and J. Patrick (1986) Molecular biology of muscle and neural acetylcholine receptors. In Nicotinic Acetylcholine Receptor Structure and Function, A. Maelicke, ed., pp. 360-387, Springer-Verlag, Heidelberg.

Huganir, R., A. Delcour, P. Grecngard, and G. Hess (1986) Phosphorylation of the nicotinic acetylcholine receptor regulates its rate of desensitization. Nature 321: 774-777.

Kao, P., and A. Karlin (1986) Acetylcholine receptor binding site contains a disulfide crosslink between adjacent half-cystinyl residues. J. Biol. Chem. 261: 8085-8088.

Kao, P., A. Dwork, R. Kaldany, M. Silver, J. Wideman, S. Stein, and A. Karlin (1984) Identification of the $\alpha$ subunit half cystine specifically labeled by an affinity reagent for the acetylcholine receptor binding site. J. Biol. Chem. 259: 11662-11665.

Kohn J., and M. Wilchek (1982) A new approach (cyano-transfer) for cyanogen-bromide activation of sepharose at neutral $\mathrm{pH}$, which yields activated resins free of interfering nitrogen derivatives. Biochem. Biophys. Res. Commun. 107: 878-884.

Kubo, T., M. Noda, T. Takai, T. Tanabc, T. Kayano, S. Shimizu, K. Tanaka, H. Takahashi, T. Hirose, S. Inayoma, R. Kikuno, T. Miyata and S. Numa (1985) Primary structure of $\alpha$ subunit precursor of calf muscle acetylcholine receptor deduced from cDNA sequence. Eur. J. Biochem. 149: 5-13.

Labarca, P., J. Lindstrom, and M. Montal (1984) Acetylcholine receptor in planar lipid bilayers: Characterization of the channel properties of the purified nicotinic acetylcholine receptor from Torpedo californica in reconstituted planar lipid bilayers. J. Gen. Physiol. 83: 473-496.

Labarca, P., J. Rice, D. Fredkin, and M. Montal (1985) Kinetic analysis of channel gating: Application to the cholinergic receptor channel and the chloride channel from Torpedo californica. Biophys. J. 47: $469-479$.

Laemmli, U. (1970) Cleavage of structural proteins during the assembly of the head of bacteriophage T4. Nature 227: 680-685.

La Polla, R., K. Mayne, and N. Davidson (1984) Isolation and characterization of a cDNA clone for the complete protein coding region of the $\alpha$ subunit of the mouse acetylcholine receptor. Proc. Natl. Acad. Sci. USA 81: 7970-7974.

Lindstrom, J., B. Walter, and B. Einarson (1979) Immunochemical similarities between subunits of acetylcholine receptors from Torpedo, Electrophorus, and mammalian muscle. Biochemistry 18: 4470-4480.

Lindstrom, J., W. Gullick, B. Conti-Tronconi, and M. Ellisman (1980) Proteolytic nicking of the acetylcholine receptor. Biochemistry 19: $4791-4795$

Lindstrom, J., M. Criado, M. Ratnam, P. Whiting, S. Ralston, J. Rivier, V. Sarin, and P. Sargent (1987a) Using monoclonal antibodies to determine the structures of acetylcholine receptors from electric organs, muscles, and neurons. Ann. NY Acad. Sci. 505: 208-225.

Lindstrom, J., R. Schoepfer, and P. Whiting (1987b) Molecular studies of the neuronal nicotinic acetylcholine receptor family. Mol. Neurobiol. 1: 281-337.

Lindstrom, J., G. D. Shelton, and Y. Fujii (1988) Myasthenia gravis. Adv. Immunol. 42: 233-284.

Lipton, S., E. Aizenman, and R. Loring (1987) Neural nicotinic acetylcholine responses in solitary mammalian retinal ganglion cells. Pfluegers Arch. 410: 37-43.

Lukas, R. (1986a) Characterization of curaremimetic neurotoxin bind- ing sites on membrane fractions derived from the human medulloblastoma clonal line TE671. J. Neurochem. 46: 1936-1941

Lukas, R. (1986b) Immunochemical and pharmacological distinctions between curaremimetic neurotoxin binding sites of central, autonomic, and peripheral origin. Proc. Natl. Acad. Sci. USA 83: $5741-$ 5745 .

Margiotta, J., D. Berg, and V. Dionne (1987) The properties and regulation of functional acetylcholine receptors on chick ciliary ganglion neurons. J. Neurusci. 7: 3612-3622.

McCallister, R. M., J. Melnyk, J. Z. Finklestein, E. C. Adams, and M B. Gardner (1969) Cultivation in vitro of cells derived from a human rhabdomyosarcoma. Cancer 24: 520-526.

McAllister, R., H. Isaacs, R. Rongey, M. Peer, W. Au, S. Sonkup, and M. Gardner (1977) Establishment of a human medulloblastoma cell line. Int. J. Cancer 20: 206-212.

Middleton, P., F. Jaramillo, and S. Scheutze (1986) Forskolin increases rate of acetylcholine receptor desensitization at rat soleus end plates. Proc. Natl. Acad. Sci. USA 83: 4967-4971.

Miles, K., D. Anthony, L. Rubin, P. Greengard, and R. Huganir (1987) Regulation of nicotinic acetylcholine receptor phosphorylation in rat myotubes by forskolin and cAMP. Proc. Natl. Acad. Sci. USA 84 . 6591-6595.

Mishina, M., T. Takai, K. Imoto, M. Noda, T. Takahashi, S. Numa, C. Methfessel, and B. Sakmann (1986) Molecular distinction between fetal and adult forms of muscle acetylcholine receptor. Nature 321: 406-411.

Momoi, M., and V. Lennon (1982) Purification and biochemical characterization of nicotinic acetylcholine receptors of human muscle. $\mathrm{J}$. Biol. Chem. 257: 12757-12764.

Montal, M., R. Anholt, and P. Labarca (1986) The reconstituted acetylcholine receptor. In Ion Channel Reconstitution, C. Miller, ed., pp. 157-204, Plenum, New York.

Nef, P., A. Mauron, R. Stalder, C. Alliod, and M. Ballivet (1984) Structure, linkage, and sequence of the two genes encoding the $\alpha$ and $\gamma$ subunits of the nicotinic acetylcholine receptor. Proc. Natl. Acad. Sci. USA 81: 7975-7979.

Neher, E., and B. Sakmann (1976) Single-channel currents recorded from membrane of dennervated frog muscle. Nature 260: 799-801.

Noda, M., H. Takahashi, T. Tanabe, M. Toyosato, Y. Furutani, T. Hirose, M. Asai, S. Inayama, T. Miyata, and S. Numa (1982) Primary structure of $\alpha$-subunit precursor of Torpedo californica acetylcholine receptor deduced from cDNA sequence. Nature 299: 793797

Noda, M., Y. Furutani, H. Takahashi, M. Toyosato, T. Tanabe, S. Shimizu, S. Kikyotani, T. Kayano, T. Hirose, S. Inayama, and S. Numa (1983a) Cloning and sequence analysis of calf cDNA and human genomic DNA encoding $\alpha$ subunit precursor of muscle acetylcholine receptor. Nature $305: 818-823$.

Noda, M., H. Takahashi, T. Tanabe, M. Toyosato, S. Kikyotani, Y. Furutani, T. Hirose, H. Takashima, S. Inayama, T. Miyata, and S. Numa (1983b) Structural homology of Torpedo californica acetylcholine receptor subunits. Nature 302: 528-532.

Noda, M., H. Takahashi, T. Tanabe, M. Toyosato, S. Kikyotani, T. Hirose, M. Asai, H. Takashima, S. Inayama, T. Miyata, and S. Numa (1983c) Primary structures of $\beta$ - and $\delta$-subunit precursor of Torpedo californica acetylcholine receptor deduced from cDNA sequences. Nature 301: 251-255.

Oakley, B., D. Drisch, and R. Morris (1980) A simplified ultrasensitive silver stain for detecting proteins in polyacrylamide gels. Anal. Biochem. 105: 361-363.

Raftery, M., M. Hunkapillar, C. Strader, and L. Hood (1980) Acetylcholine receptor: Complex of homologous subunits. Science 208. 1454-1457.

Robinson, D., and R. McGee (1985) Agonist-induced regulation of the neuronal nicotinic acetylcholine receptor of PC12 cells. Mol. Pharmacol. 27: 409-417.

Sakmann, B., and E. Neher (1983) Single Channel Recording, Plenum, New York.

Sanger, F., S. Nicklen, and A. R. Coulson (1977) DNA sequencing with chain-terminating inhibitors. Proc. Natl. Acad. Sci. USA 74 . 5463-5467.

Schoepfer, R., M. Luther, and J. Lindstrom (1988) The human medulloblastoma cell line TE671 expresses a muscle-like acetylcholine receptor: Cloning of the $\alpha$ subunit cDNA. FEBS Lett. 226: 235-240.

Schubert, D., A. J. Harris, C. E. Devine, and S. Heinemann (1974) 
Characterization of a unique muscle cell line. J. Cell Biol. 61: 398413.

Schuetze, S., and L. Role (1987) Developmental regulation of nicotine acetylcholine receptors. Annu. Rev. Neurobiol. 10: 403-457.

Schuetze, S., S. Vicini, and Z. Hall (1985) Myasthenic serum selectively blocks acetylcholine receptors with long channel open times at developing rat endplates. Proc. Natl. Acad. Sci. USA 82: 2533-2537.

Seaman, K., W. Padgett, and J. Daly (1981) Forskolin: Unique diterpene activator of adenylate cyclase in membranes and intact cells. Proc. Natl. Acad. Sci. USA 6: 3363-3367.

Siegel, H. N., and R. J. Lukas (1988) Nicotinic agonists regulate $\alpha$-Bungarotoxin binding sitcs of TE671 human medulloblastoma cells. J. Neurochem. 50: 1272-1278.

Sine, S. (1988) Functional properties of human skeletal muscle acetylcholine receptors expressed by the TE671 cell line. J. Biol. Chem. 263: 18052-18062.

Sine, S., and J. H. Steinbach (1984) Activation of nicotinic acetylcholine receptor. Biophys. J. 45: 175-185.

Smith, M., J. Margiotta, A. Franco, Jr., J. Lindstrom, and D. Berg (1986) Cholinergic modulation of an acetylcholine receptor-like antigen on the surface of chick ciliary ganglion neurons in cell culture. J. Neurosci. 6: 946-953.

Smith, M., J. Merlie, and J. Lawrence (1987) Regulation of phosphorylation of nicotinic acetylcholine receptors in mouse $\mathrm{BC} 3 \mathrm{H}-1$ myocytes. Proc. Natl. Acad. Sci. USA 84: 6601-6605.

Stratton, M. R., B. R. Recves, and C. S. Cooper (1989) (Letter to the Editor) Nature 337: 311-312.

Syapin, P., P. Salvaterra, and J. Engelhardt (1982) Neuronal-like features of TE671 cells: Presence of a functioning nicotinic cholinergic receptor. Brain Res. 231: 365-377.

Turnbull, G., R. Harrison, and G. Lunt (1985) Nicotinic acetylcholine receptor from foetal human skeletal muscle. Int. J. Dev. Neurosci. 3: 123-134.

Tzartos, S., D. Rand, B. Einarson, and J. Lindstrom (1981) Mapping of surface structures on electrophorus acetylcholine receptor using monoclonal antibodies. J. Biol. Chem. 256: 8635-8645.
Tzartos, S., S. Hochschwender, L. Langeberg, and J. Lindstrom (1983) Demonstration of a main immunogenic region on acetylcholine receptors from human muscle using monoclonal antibodies to human receptor. FEBS Lett. 158: 116-118.

Tzartos, S., L. Langeberg, S. Hochschwender, L. Swanson, and J. Lindstrom (1986) Characteristics of monoclonal antibodies to denatured Torpedo and to native calf acetylcholine receptors: Species, subunit, and region specificity. J. Neuroimmunol. 10:235-253.

Tzartos, S., S. Hochschwender, P. Vasquez, and J. Lindstrom (1987) Passive transfer of experimental autoimmune myasthenia gravis by monoclonal antibodies to the main immunogenic region of the acetylcholine receptor. J. Neuroimmunol. 15: 185-194.

Wagoner, P., and B. Pallotta (1988) Modulation of acetylcholine receptor desensitization by forskolin is independent of cAMP. Science 240: 1655-1657.

Weinberg, C., and Z. Hall (1979) Antibodies from patients with myasthenia gravis recognize determinants unique to extrajunctional acetylcholine receptors. Proc. Natl. Acad. Sci. USA 76: 504-508.

Wennogle, L., R. Oswald, T. Saitch, and J.-P. Changeux (1981) Dissection of the 66,000 dalton subunit of the acetylcholine receptor Biochemistry 20: 2492-2497.

Whiting, P., and J. Lindstrom (1987) Affinity labeling of neuronal acetylcholine receptors localizes the neurotransmitter binding site to the $\beta$ subunit. FEBS Lett. 213: 55-60.

Whiting, P., and J. Lindstrom (1988) Characterization of bovine and human neuronal nicotinic acetylcholine receptors using monoclonal antibodies. J. Neurosci. 8: 3395-3404.

Whiting, P., A. Vincent, M. Schluep, and J. Newsom-Davis (1986) Monoclonal antibodies that distinguish between normal and denervated human acetylcholine receptor. J. Neuroimmunol. 11: 223-235.

Whiting, P., J. Cooper, and J. Lindstrom (1987) Antibodies in sera from patients with myasthenia gravis do not bind to acetylcholine receptors from human brain. J. Neuroimmunol. 16: 205-213.

Witzemann, V., B. Barg, Y. Nishikawa, B. Sakmann, and S. Numa (1987) Differential regulation of muscle acetylcholine receptor $\gamma$ and $\epsilon$ subunit mRNAs. FEBS Lett. 223: 104-112. 